\title{
Targeting histone methylation for cancer therapy: enzymes, inhibitors, biological activity and perspectives
}

\author{
Yongcheng Song ${ }^{1,2^{*}}$, Fangrui $\mathrm{Wu}^{1}$ and Jingyu $\mathrm{Wu}^{1}$
}

\begin{abstract}
Post-translational methylation of histone lysine or arginine residues plays important roles in gene regulation and other physiological processes. Aberrant histone methylation caused by a gene mutation, translocation, or overexpression can often lead to initiation of a disease such as cancer. Small molecule inhibitors of such histone modifying enzymes that correct the abnormal methylation could be used as novel therapeutics for these diseases, or as chemical probes for investigation of epigenetics. Discovery and development of histone methylation modulators are in an early stage and undergo a rapid expansion in the past few years. A number of highly potent and selective compounds have been reported, together with extensive preclinical studies of their biological activity. Several compounds have been in clinical trials for safety, pharmacokinetics, and efficacy, targeting several types of cancer. This review summarizes the biochemistry, structures, and biology of cancer-relevant histone methylation modifying enzymes, small molecule inhibitors and their preclinical and clinical antitumor activities. Perspectives for targeting histone methylation for cancer therapy are also discussed.
\end{abstract}

Keywords: Histone methylation, Enzyme inhibitor, Histone lysine methyltransferase, Protein arginine methyltransferase, Histone demethylase, Cancer therapeutics

\section{Background}

Nucleosome is the smallest structural unit of the human genetic material, which is composed of $\sim 146$ base pairs of double-stranded DNA wrapped around a histone octamer that contains two copies of histone H2A, H2B, $\mathrm{H} 3$, and $\mathrm{H} 4$ proteins. Basic lysine and arginine residues are enriched in histones. At physiological $\mathrm{pH}$, these positively charged sidechains provide strong electrostatic and $\mathrm{H}$-bond interactions with the negatively charged DNA for tight binding and packaging. Chromatin, a linear array of millions of nucleosomes, is organized into higher orders of structure and tightly condensed to form a chromosome. Functionally, chromatin is classified into highly packed, transcriptionally inactive heterochromatin and transcriptionally active euchromatin, whose structure is less condensed and DNA is therefore more

\footnotetext{
* Correspondence: ysong@bcm.edu

'Department of Pharmacology, Baylor College of Medicine, 1 Baylor Plaza, Houston, TX 77030, USA

${ }^{2}$ Dan L. Duncan Cancer Center, Baylor College of Medicine, 1 Baylor Plaza, Houston, TX 77030, USA
}

accessible to a transcription machinery $[1,2]$. Posttranslational modifications of histones, such as acetylation and methylation, largely control DNA accessibility and regulate gene expression. For example, acetylation can neutralize the positive charged lysine sidechain and render a more open DNA structure to facilitate the binding of transcription factors as well as other proteins for gene expression. Abnormal histone modifications often occur in many diseases such as cancer. Histone modifying enzymes are therefore potential drug targets for these diseases [3, 4]. Small molecule inhibitors of histone deacetylases (HDAC) have been extensively developed and several compounds, such as vorinostat and romidepsin, have been approved to treat $\mathrm{T}$-cell lymphomas [5-7]. Moreover, HDAC inhibitors have been in many clinical trials for other hematologic and solid cancers, with $>500$ studies in clinicaltrials.gov.

Physiological and pathological functions of histone methylation in a lysine or arginine residue have been well studied and documented. These post-translational modifications play crucial roles in gene regulation, cell 
differentiation, DNA recombination, and damage repair in normal cells as well as pathogenesis in diseases $[4,8]$. A large family of $\geq 60$ histone methyltransferases (HMT), including histone lysine methyltransferases (HKMT) and protein/histone arginine methyltransferases (PRMT), were identified in humans, among which the biochemical and biological functions of many methyltransferases have been characterized [9, 10]. In addition, histone methylation is dynamically controlled by histone/protein lysine demethylases (KDM), enzymes that remove the methyl group(s) from a methylated lysine sidechain [1113]. The opposite functions between HMTs and KDMs facilitate to maintain balanced histone methylation levels. Aberrant histone methylations have been frequently found in cancer $[4,8]$, caused by a gene mutation, translocation, or dysregulated expression. Therefore, many HMTs and KDMs are potential drug targets and small molecule inhibitors of these proteins are useful chemical probes or potential therapeutics. As compared to that of HDAC inhibitors, development of histone methylation modulators has been in an early stage $[4,14]$. There were very few potent inhibitors of HMTs and KDMs before 2010. Significantly more efforts from the academia and pharmaceutical industry have been observed during the past few years, leading to a rapidly increased number of small molecule modulators of histone methylation [15-17]. Several potent and selective compounds have recently been in clinical trials against acute myeloid leukemia (AML), nonHodgkin lymphoma and lung cancer, showing the great potential for this class of compounds in cancer therapy.

This review summarizes the biochemistry, structures, and biology of histone methylation modifying enzymes, small molecule inhibitors and their preclinical and clinical antitumor activities. Due to the large number of these proteins, only those highly relevant to cancer are described, with a particular focus on histone H3 lysine 79 (H3K79) methyltransferase DOT1L, H3K4 targeting mixed lineage leukemia (MLL) and lysine-specific demethylase 1 (LSD1), and H3K27 methyltransferase EZH2. We also include mutations of isocitrate dehydrogenases (IDH), which have recently been found in $20-80 \%$ of gliomas, AML and several types of sarcomas. The mutant IDH proteins indirectly inhibit a broad range of histone demethylases and cause genome-wide histone hypermethylation. In addition, perspectives of targeting histone methylation for cancer therapy are discussed.

\section{Biochemistry and structure}

HMTs belong to a superfamily of methyltransferases containing $>100$ members from bacteria to humans $[9$, $10,18,19]$. In addition to the lysine and arginine sidechains of a protein, methyltransferases can methylate DNA, RNA and even small molecules such as a catecholamine. The methyl acceptors for these enzymes can be a $\mathrm{N}$ (e.g., $-\mathrm{NH}_{2}$ of a lysine), $\mathrm{C}$ (e.g., C5-cytosine in DNA), or $\mathrm{O}$ (e.g., $-\mathrm{OH}$ of a catecholamine) atom. All methyltransferases use S-adenosylmethionine (SAM) as the enzyme cofactor, with its methyl group (activated by the sulfonium) being the donor. Figure 1a schematically illustrates the general mechanism of catalysis of an HMT. SAM and the substrate histone lysine bind to different binding pockets of HMT in an orientation that brings the methyl donor and acceptor atoms to a close proximity, which facilitates the ensuing nucleophilic substitution reaction to occur, producing the methylated histone and S-adenosylhomocysteine (SAH).

Based on X-ray crystallographic studies, there are five classes of methyltransferases with distinct structural features $[9,10]$. It is of interest that H3K79 methyltransferase DOT1L and all PRMTs belong to class I methyltransferases and share high similarities. However, all other HKMTs are class V methyltransferases containing a SET (Su(var)3-9, Enhancer-of-zeste, Trithorax) domain, having a distinct structure from DOT1L. Figure 1b, c show the overall structures as well as the close-up views of the active sites of DOT1L and H3K9 methyltransferase G9a, respectively. DOT1L is a typical class I methyltransferase [20], characterized by an overall protein structure of 7 stranded $\beta$ sheets flanked by several $\alpha$ helices, as well as an extended binding conformation of SAM (Fig. 1b). The SAM-binding pocket is deeply buried inside the protein. While there has been no structural information as to how nucleosome (the substrate) binds to DOT1L, the substrate-binding pocket is largely separated from that of SAM, interconnected by a narrow lysine binding channel. The class V methyltransferase G9a is a structurally distinct protein, consisting of mostly $\beta$ sheets interlinked by loops (Fig. 1c) [21]. SAM/SAH adopts a kinked binding conformation in this class of HMTs.

For the opposite reaction, there are two families of KDMs that can oxidatively remove the methyl group from a methylated lysine sidechain using distinct mechanisms. LSD1 (also known as KDM1A) and its homolog LSD2 (also known as KDM1B) are flavin adenine dinucleotide (FAD) dependent monoamine oxidases (MAO) [22, 23]. As shown in Fig. 2a, the methyl group of a methylated lysine is oxidized by the cofactor FAD to form an imine intermediate, which hydrolyzes to give the demethylated product and formaldehyde. $\mathrm{FADH}_{2}$, the reduced form of the cofactor, is oxidized by $\mathrm{O}_{2}$ to generate FAD and $\mathrm{H}_{2} \mathrm{O}_{2}$ to complete a catalytic cycle. Because the formation of an imine intermediate is required, LSD1/2 can only demethylate a mono- or di-methylated lysine, but not a trimethylated lysine. Figure $2 \mathrm{~b}$ shows the X-ray crystal structure of LSD1 in complex with FAD and its H3K4 peptide substrate (with K4M mutation) [24]. FAD is tightly bound inside LSD1, with its aromatic tricyclic flavin ring being part of the large substrate-binding pocket, which can 


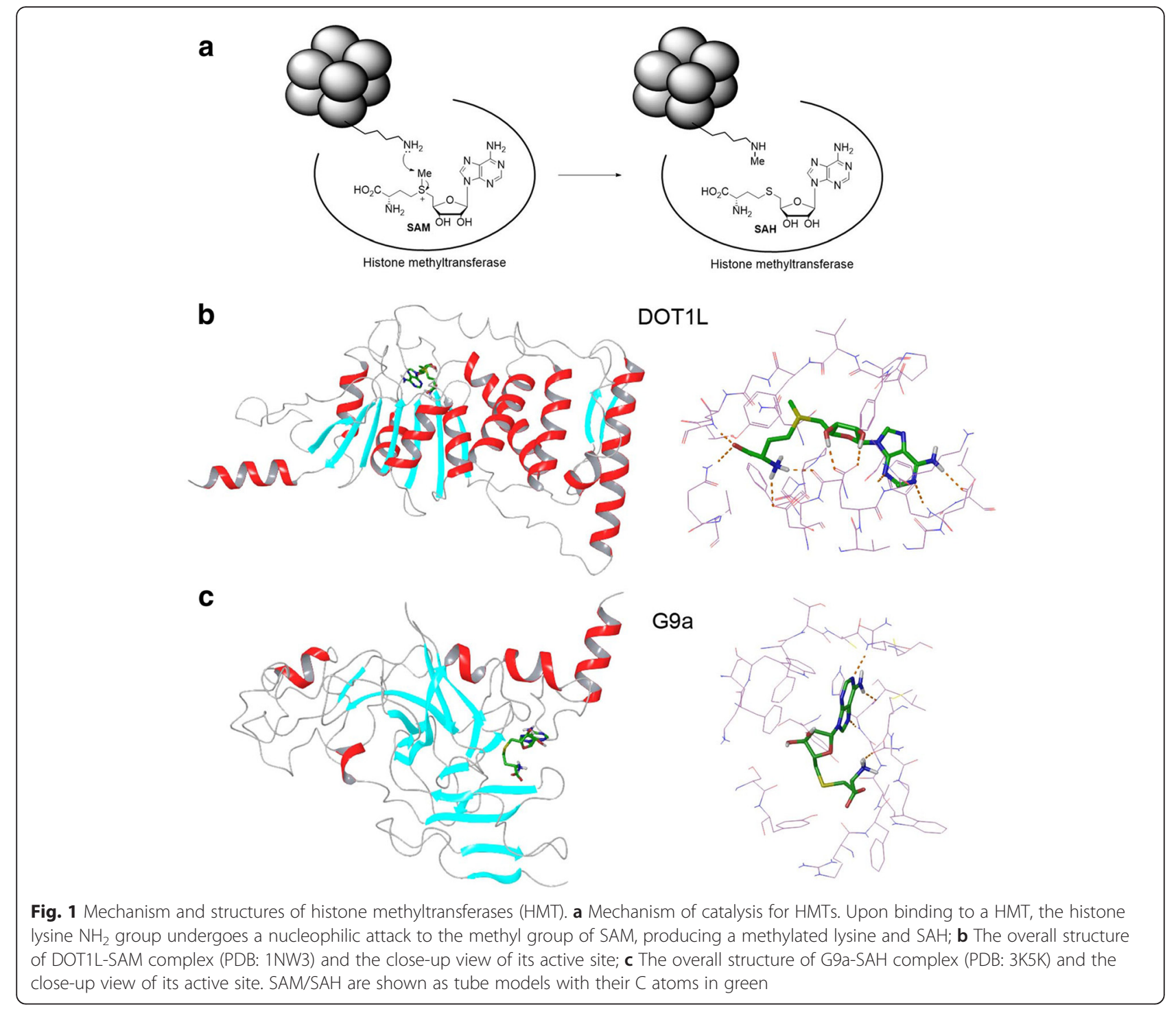

accommodate and recognize the histone $\mathrm{H} 3$ peptide. The sidechain of Lys4 (mutated to Met) residue is located in proximity to the flavin ring for oxidation.

The other family, consisting of $\sim 30 \mathrm{KDMs}$ including KDM2 - 7 and PHF (plant homeodomain finger) in humans, all contain a JmjC domain and are $\mathrm{Fe}(\mathrm{II})$ and $\alpha$ ketoglutarate $(\alpha-K G)$ dependent dioxygenases $[13,25,26]$. Figure $2 \mathrm{c}$ illustrates the general mechanism of catalysis for these enzymes [27, 28]. An oxygen molecule coordinates to $\mathrm{Fe}(\mathrm{II})$ and oxidizes both $\mathrm{Fe}(\mathrm{II})$ and $\alpha-\mathrm{KG}$ to give (upon decarboxylation) a succinate and $\mathrm{Fe}(\mathrm{IV})$-oxo intermediate. Next, the Fe(IV) species oxidizes the $\mathrm{C}$ atom of the methylated lysine to form a hydroxymethylamine intermediate, which hydrolyzes to produce the demethylated product and formaldehyde. Unlike LSD1/2, the JmjC family of KDMs can demethylate mono-, di-, and tri-methylated lysine. Figure $2 \mathrm{~d}$ shows the X-ray structure of PHF8 in complex with $\mathrm{Fe}^{2+}$, an $\alpha-\mathrm{KG}$ analog and a methylated histone $\mathrm{H} 3$ peptide [29]. The central metal ion is coordinated with an Asp and two His residues, together with two $\mathrm{O}$ atoms of $\alpha-K G$. One of the methyl groups of H3K9me2 sidechain is located closely to the metal ion.

To date, six lysine residues in histone $\mathrm{H} 3$ and H4, i.e., H3K4, K9, K27, K36, K79, and H4K20, have been found to be methylated. Figure 3 illustrates the substratespecificity of HKMs and KDMs. Many other lysine residues, including $\mathrm{H} 3 \mathrm{~K} 14,18,23$, and $\mathrm{H} 4 \mathrm{~K} 5,8,12$, and 16 , are not methylated. Rather, they can be acetylated. It is also of interest that H3K9 and K27 can also be acetylated. Mutually exclusive acetylation or methylation at H3K9 and K27 appears to play drastically distinct physiological functions. Acetylated H3K9 and K27 cause activated gene transcription, while methylated H3K9 and K27 are transcriptional repressive. 

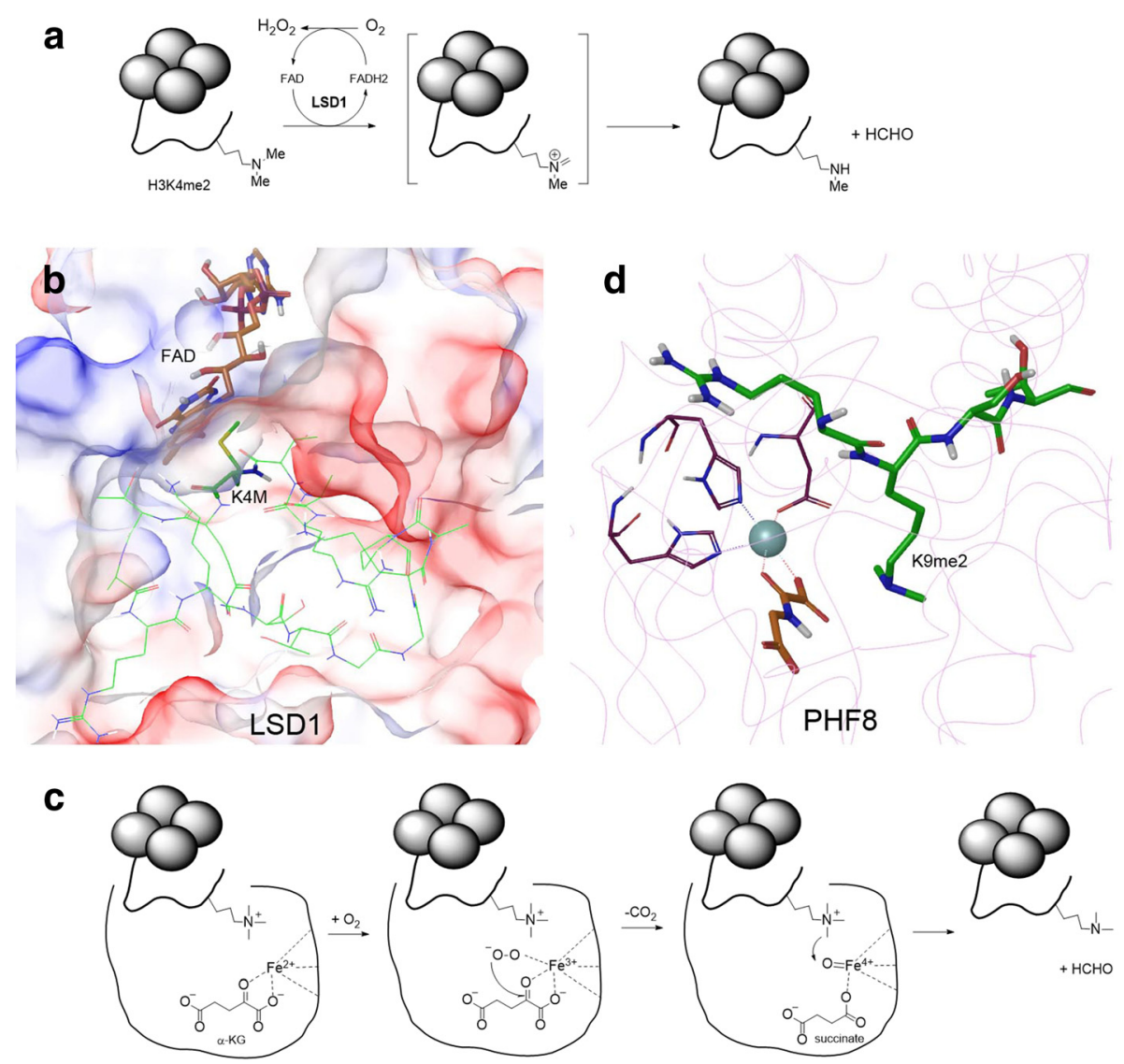

Fig. 2 Mechanisms and structures of histone lysine demethylases (KDM). a Mechanism of catalysis for FAD dependent KDM1 proteins (including LSD1 and 2); $\mathbf{b}$ The active site of LSD1 in complex with FAD and a histone H3 peptide (PDB: 2V1D). LSD1 is shown as a $50 \%$ transparent electrostatic surface. The peptide is shown as a wire model (C atoms in green), with the K4M residue highlighted as a tube model; c Mechanism of catalysis for JmjC domain KDMs; $\mathbf{d}$ The active site of PHF8 in complex with Fe ${ }^{2+}$ (cyan sphere), an a-KG analog (brown) and a histone H3 peptide (green) (PDB: 3KV4)

\section{H3K79 methyltransferase DOT1L}

DOT1L's physiological function and pathogenesis in leukemia

DOT1L (disruptor of telomeric silencing 1 like) was identified as a human homolog of yeast DOT1, which was found to disrupt telomeric silencing in budding yeast in a genetic screen [30]. The full-length human DOT1L has 1537 amino acids, with its highly conserved $\mathrm{N}$-terminal domain of $\sim 360$ amino acids being an H3K79 methyltransferase [31]. The remaining part of

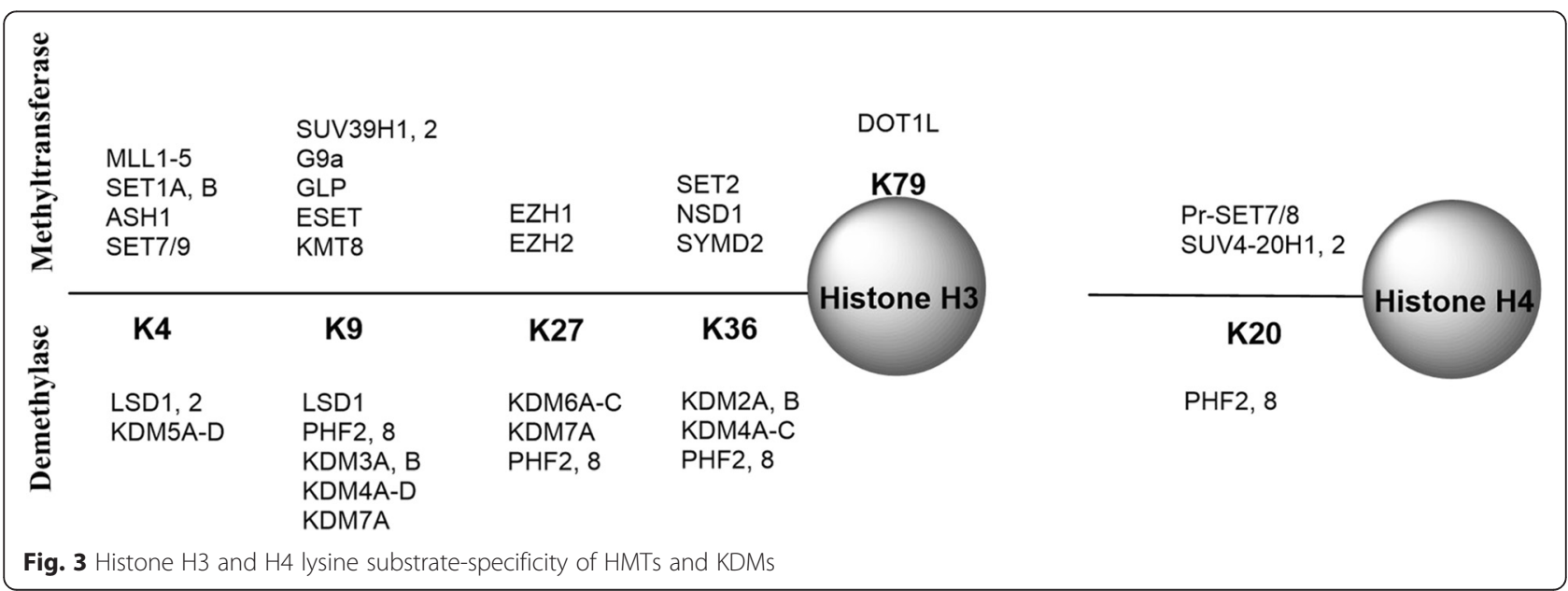


mammalian DOT1L is involved in interactions with many transcription proteins, such as AF4, AF9, AF10, and ENL [32-36]. Biology of DOT1L in health and diseases has been summarized in several recent reviews [37-39]. The biological function of DOT1L (as well as DOT1) is to methylate H3K79 as part of a transcription complex, which can initiate or maintain an active transcription state. This is supported by the genetic studies in yeast, showing $\sim 10 \%$ genome containing hypomethylated H3K79 are located at transcriptionally inactive loci, while the remaining $90 \%$ genes with an H3K79 methyl marker are actively transcribed $[40,41]$. This also occurs in Drosophila and mammals [42, 43]. Several large transcription protein complexes containing DOT1L have been purified and identified using chromatin immunoprecipitation, including ENL-associated proteins (EAP), DOT1Lcontaining complex (DotCom), and Super elongation complex (SEC) [32-36]. Several transcription relevant proteins were repeatedly present in these complexes, including transcription factors AF4, AF9, AF10, and ENL, as well as P-TEFb kinase. P-TEFb is a cyclin-dependent kinase that can phosphorylates RNA polymerase II, which is required for transcription elongation. These strongly support DOT1L as well as H3K79 methylation is crucial to gene transcription.

DOT1L plays important roles in normal physiology of an organism. For embryonic development, methylation at H3K79 is absent in the very early stage and increasing levels of H3K79me2 can be found in later stages, suggesting this "histone code" is important for embryonic development [44, 45]. Germline knockout of mouse DOT1L was embryonic lethal and major defects in the cardiovascular system were found in the knockout embryos [46]. Additionally, DOT1L has been found to be crucial for maintaining normal hematopoiesis in mice $[47,48]$. Conditional knockout of DOT1L in bone marrow significantly decreased hematopoietic stem cells as well as all types of progenitor cells. Moreover, other studies have shown DOT1L plays roles in maintaining normal functions of heart and kidney [46, 49-51].

DOT1L has been found to be a drug target for acute leukemia with a mixed lineage leukemia (MLL, also known as MLL1 or KMT2A) gene translocation. This subtype of leukemia accounts for $\sim 75 \%$ of acute leukemia in infants and $\sim 10 \%$ in children and adults [52-54] with a particularly poor prognosis [55-58]. The phenotype of MLL-rearranged leukemia can be acute myeloid leukemia (AML), acute lymphoid leukemia (ALL), or mixed lineage leukemia. However, despite phenotypic differences, gene profiling showed these MLL-rearranged leukemias share a similar gene expression signature [59]. The biology of MLL and leukemogenesis of MLL-rearranged oncogenes have been well studied and reviewed [60-62]. Briefly, MLL is a large, multi-domain protein (3969 amino acids), containing an N-terminal AT hook domain that recognizes and binds to DNA as well as a C-terminal SET domain that is an H3K4 methyltransferase [52]. Figure 4a schematically illustrates the biology of MLL for gene expression in normal cells. Upon binding to the promoter region of its target genes, the SET domain of MLL can

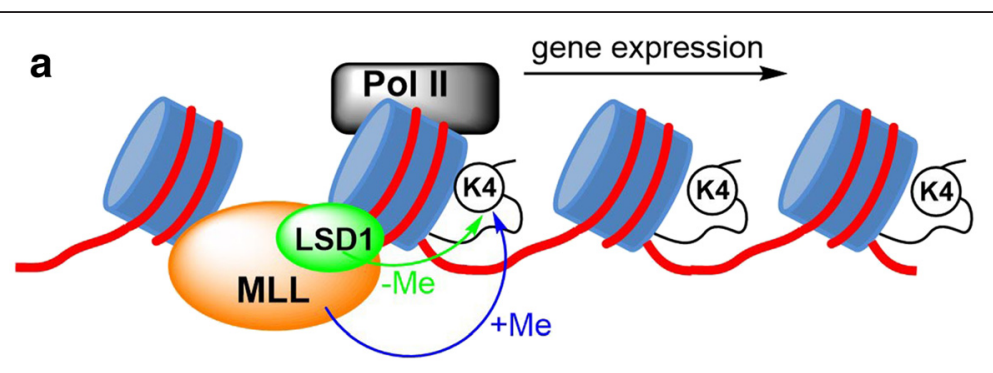

b

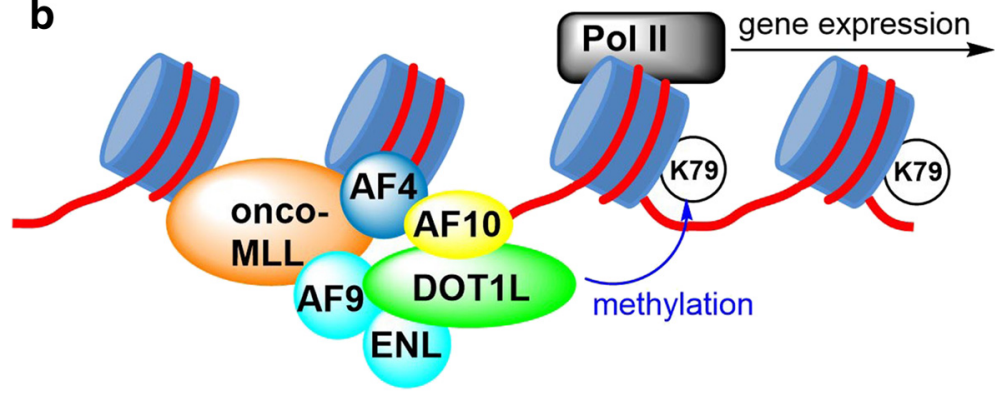

Fig. 4 Functions of wild-type MLL, LSD1 and onco-MLL fusion proteins. a MLL methylates H3K4 and initiates RNA polymerase II (Pol II) mediated gene transcription, while LSD1 removes the methyl group from H3K4me1 and 2 and keeps a balanced H3K4 methylation; b The onco-MLL protein complex involving AF4, AF9, AF10, or ENL can recruit DOT1L, which methylates H3K79 and causes overexpression of leukemia-relevant genes 
methylate H3K4, which also represents a histone marker for active gene transcription [63, 64]. In the leukemia, the chromosome rearrangement replaces the C-terminal part of MLL with a fusion partner gene [52, 53, 65]. The SET domain as well as its H3K4 methylation activity is thus lost. To date, although $>70$ partner genes have been documented, onco-MLLs fused with transcription factors AF4, AF9, AF10, and ENL account for the majority (>70 \%). As shown in Fig. $4 \mathrm{~b}$, these four proteins are able to recruit DOT1L into the MLL transcription complex, which subsequently methylates H3K79 [32, 34, 51, 66, 67]. This aberrant epigenetic event dysregulates the expression of many MLL target genes, such as HoxA9, HoxA7, and Meis1 whose overexpression can cause leukemia. Abnormal H3K79 methylation has been observed in the clinic as well as mouse models of MLL-rearranged leukemia and becomes hallmarks of this malignancy. DOT1L therefore represents a drug target for MLL leukemias. Indeed, this has been established by biological means (e.g., knockdown by RNA interference) [66] and pharmacological inhibition as described below [68-76].

DOT1L inhibitors and their activity against MLL leukemia Because of DOT1L's crucial role in oncogenesis and maintenance of MLL-rearranged leukemia, much effort has been dedicated to find small molecule inhibitors of DOT1L. The first DOT1L inhibitor EPZ004777 (1, Fig. 5) as well as its selective antitumor activity against MLL leukemia were reported in 2011 [68]. Several other potent DOT1L inhibitors were disclosed shortly after [6975]. Figure. 5 summarizes representative inhibitors of DOT1L, as well as their biochemical and antitumor activities. It is noted that all currently disclosed DOT1L inhibitors contain an adenosine or its analogous structure and are competitive to the enzyme cofactor SAM. This is likely because of the difficulty to compete with the substrate nucleosome, which has strong proteinprotein and protein-DNA interactions with DOT1L [70].

The discovery of compound 1 followed a conventional ligand-based medicinal chemistry approach [69]. Starting with the natural inhibitor SAH $\left(K_{\mathrm{i}}=260 \mathrm{nM}\right)$, a series of repeated cycles of chemical modifications followed by structure activity relationship studies yielded 1, which still has an adenosine-like moiety, while the sidechain in SAH is replaced with a tert-butylphenyl urea containing tertiary amine group. Compound 1 exhibited an extremely potent inhibitory activity against DOT1L with a $K_{\mathrm{i}}$ value of $0.3 \mathrm{nM}, \sim 860$-fold more active than SAH. In addition, unlike SAH being a broadly active inhibitor of HMTs, 1 shows an excellent enzyme selectivity profile: it did not inhibit a panel of 8 other HMTs at $50 \mu \mathrm{M}$, although 1 is a relatively weak inhibitor of PRMT5 $\left(\mathrm{IC}_{50}\right.$ : $520 \mathrm{nM}$ ). X-ray crystallographic studies showed that the binding of compound 1 causes large protein conformational changes of DOT1L to accommodate the large hydrophobic sidechain [69]. Surface plasmon resonance (SPR) studies revealed that a very slow $k_{\text {off }}$ rate mostly accounts for the potent inhibitory activity of compound 1. Further inhibitor optimization produced EPZ-5676 (2) with an improved activity $\left(K_{\mathrm{i}}=0.08 \mathrm{nM}\right)$ as well as cellular activities [73]. Several other groups also disclosed their DOT1L inhibitors. Structure-based design led to the finding of compound 3, a N6-methyl substituted $\mathrm{SAH}$, which retains the inhibitory activity of SAH

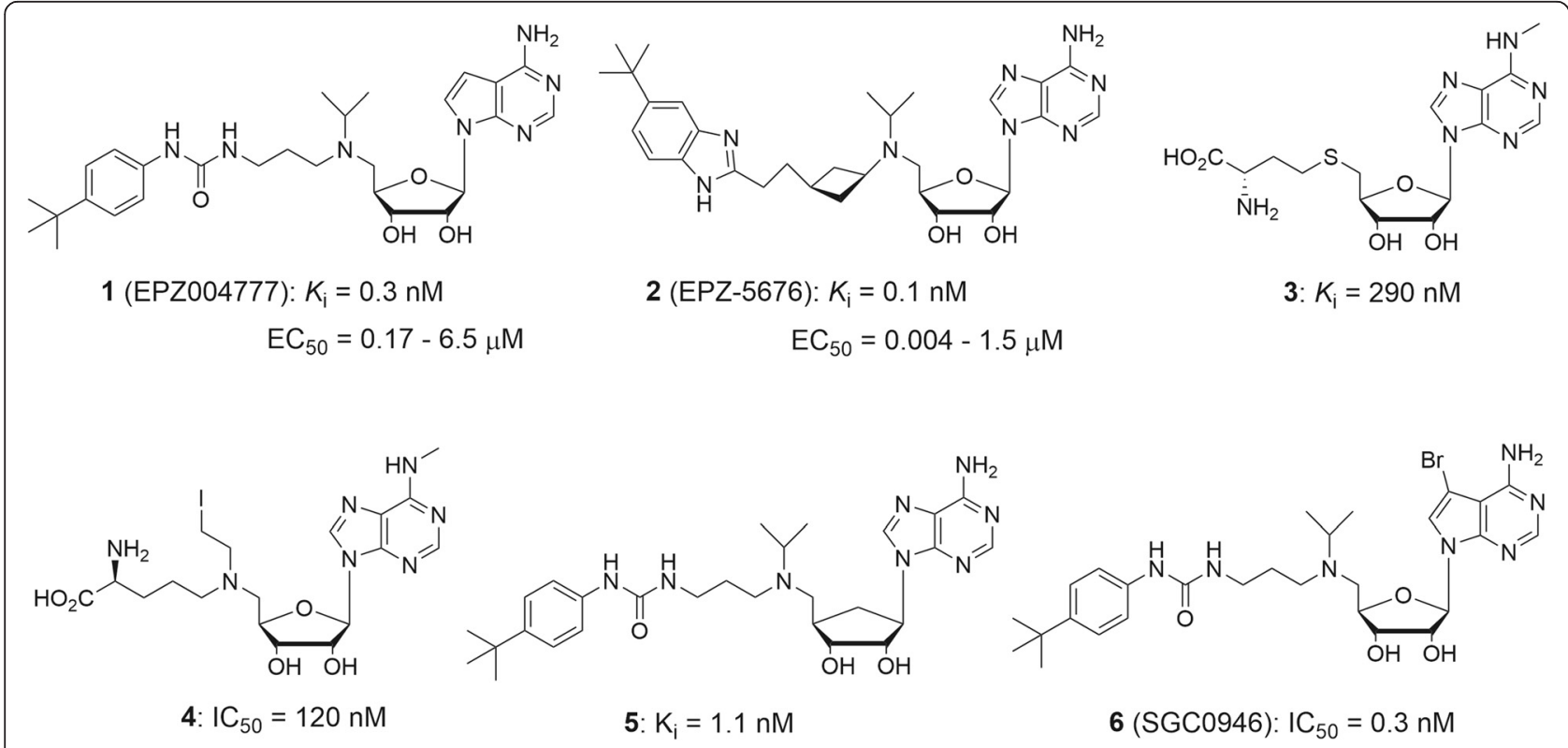

Fig. 5 Structures and activities of representative DOT1L inhibitors 
against DOT1L and exhibits excellent selectivity against other HMTs [71]. Compound 4 is a potent, mechanismbased inhibitor of DOT1L, with the ability to covalently bind to the substrate [71]. Compounds 5 and 6 are analogs of 1 and also showed highly potent inhibition against DOT1L $\left(K_{\mathrm{i}}=1.1\right.$ and $\left.0.06 \mathrm{nM}\right)[75,76]$. Compound 5 with a cyclopentane ring (rather than the ribose in other compounds) was designed, synthesized and shown to retain a potent inhibitory activity against DOT1L. However, it exhibited a significantly improved metabolic stability [75]. X-ray structure-based design for compound 6 with a 7 -bromo substituent on the adenine ring was intended to exploit a nearby hydrophobic pocket and it turned out that 6 is one of the most potent inhibitors of DOT1L [76].

Compounds 1, 2, 5, and 6 are cell permeable and exhibit selective activities against MLL-rearranged leukemia cells $[68,73,75]$. It is remarkable that these DOT1L inhibitors are not cytotoxic and did not exhibit anti-proliferative activity for a short (e.g., 3 days) treatment. Rather, a long time (e.g., 14 days) incubation is needed, showing a distinct mechanism of action for these compounds $[69,70]$. The slow action is likely because of a long time required for a series of cellular events that arrest cell growth, including H3K79 methylation inhibition, followed by systematic changes of gene expression. Compound 1 only inhibited cellular $\mathrm{H} 3 \mathrm{~K} 79$ methylation with an $\mathrm{IC}_{50}$ of $\sim 50$ $\mathrm{nM}$ and did not affect other histone methylations significantly. 1 inhibited the proliferation of MLL-rearranged leukemia cells with $\mathrm{EC}_{50}$ values of $0.17-6.5 \mu \mathrm{M}$, while it showed significantly reduced activity against leukemia cells without a MLL rearrangement $\left(\mathrm{EC}_{50}\right.$ : $\left.13.9->50 \mu \mathrm{M}\right)$. Treatment with 1 caused downregulation of onco-MLL target genes and induced cell differentiation as well as apoptosis of MLL-rearranged leukemia cells. Gene profiling also revealed that there were significant overlaps in gene expression pattern between samples treated with compound 1 and DOT1L knockdown, supporting DOT1L is the cellular drug target. Due to the poor pharmacokinetics, continuous infusion using an osmotic pump was chosen for administration of compound $\mathbf{1}$ for in vivo studies. A dose of $70 \mathrm{mg} / \mathrm{kg}$ for 21 days was able to cause a regression of subcutaneous tumors of MV4-11 leukemia cells. In a more clinically relevant systemic MV4-11 leukemia mouse model, compound $\mathbf{1}$ can also prolong survival of the experimental animals with statistical significance.

Compound 2 is the most potent DOT1L inhibitor, together with improved pharmacokinetics [73]. It showed more potent cellular activities (e.g., $\mathrm{EC}_{50} \mathrm{~s}=0.004-1.5 \mu \mathrm{M}$ ) and in vivo antitumor efficacy. It has been in phase I clinical trials against MLL-rearranged leukemia. Preliminary clinical results of compound 2 were disclosed in the $56^{\text {th }}$ Annual Meeting of American Society of Hematology [77] as well as several press releases (www.epizyme.com). A total of 37 advanced leukemia patients, who were heavily pretreated with chemotherapies, were enrolled and received 6 doses (ranging from 12 to $90 \mathrm{mg} / \mathrm{m}^{2} /$ day for 21 or 28 days) of continuous infusion of 2 . The compound was well tolerated, with the main adverse events being grade 1 or 2 leukocytosis, nausea and hypomagnesemia. Drug administration can achieve a rapid steady-state plasma concentration of compound 2 on day- 1 and cause inhibition of H3K79 methylation in patients' bone marrow as well as peripheral blood cells. Eight patients out of 34 with an MLL-translocation showed biological or clinical activity, among whom two complete responses as well as one partial response were observed. More clinical trials including combination therapies with other drugs are being conducted.

\section{DOT1L in other diseases}

DOT1L has been identified to be a drug target for several other types of cancers [78-80]. A bioinformatics search found the expression levels of DOT1L correlate with breast cancer as well as a panel of genes that promote proliferation of the malignancy [78]. Knockdown of DOT1L and pharmacological inhibition (by e.g., compound 1) showed inhibition of H3K79 methylation and cell proliferation of several DOT1L $\mathrm{L}^{+}$breast cancer cell lines with $\mathrm{EC}_{50}$ of $0.19-1.4 \mu \mathrm{M}$, while DOT1L $\mathrm{L}^{\text {low }}$ breast cancer cells were not sensitive to DOT1L inhibition. Mechanistically, inhibition of DOT1L/H3K79 methylation can impair self-renewal and metastatic potential, induce differentiation and down-regulate many pro-proliferation genes, all of which contribute to significantly reduced proliferation of these breast cancer cells. H3K79 hypermethylation was observed for lung cancer cell lines A549 and NCI-H1299. siRNA-mediated DOT1L knockdown can block the proliferation of these cells [79]. Therefore, these experiments implied that DOT1L plays an important role in lung cancer. However, no DOT1L inhibitors were tested to confirm this finding. In addition to cancer, DOT1L was recently found to play a role in cell reprogramming. DOT1L knockdown as well as compound 1 were shown to significantly increase the reprogramming efficiency of somatic cells to produce more induced pluripotent stem cells (iPSC), showing the potential of using DOT1L inhibitors in regenerative medicine [80].

\section{MLL and LSD1 modifying H3K4 methylation} Cancer biology of MLL and LSD1

The biology of MLL has been extensively studies and reviewed [52-54,60-62] and briefly summarized in the above section and here. The biological function of MLL is essential for development: knockout of MLL in mice is embryonic lethal. MLL has been found to associate with thousands of gene promoters and have a global role 
in positive regulation of transcription of many important genes such as Hox families of genes [81, 82]. Hox genes are transcriptional factors essential for the development of multiple tissues including the hematopoietic system, while overexpression of certain members (e.g., HoxA9 etc.) has been found to lead to leukemogenesis [83]. MLL gene translocations are frequently found in acute leukemia. Moreover, it is noted that MLL-translocation occurs in one allele, with the wild-type (WT) MLL in the other allele remaining intact. A recent study showed that MLL's H3K4 methyltransferase activity is essential for MLL-rearranged leukemia, suggesting inhibition of the SET domain of MLL is a possibly viable approach to MLL leukemia treatment [84].

LSD1 plays an opposite role as a histone lysine demethylase [22, 23]. LSD1 contains four functional domains, including an $\mathrm{N}$-terminal domain with a putative nuclear localization peptide, a SWIRM, and an oxidase domain, inside which there is a tower domain insert [85]. The last three domains are important for demethylation. In addition, the tower domain, which is not present in a closely related enzyme LSD2, directly interacts with CoREST (also known as RCOR1, repressor element-1 silencing transcription factor corepressor 1), through which LSD1 forms protein complexes that regulate histone lysine methylation as well as gene expression. The biological function of LSD1 is crucial, as germline LSD1 knockout in mice was found to be embryonic lethal and conditional knockout caused increased H3K4me1/2, blocked hematopoiesis and pancytopenia (low in all blood cell types) [86]. The primary substrates of LSD1 are H3K4me1 and me2, which are important histone marks for active gene transcription. LSD1 was found to be part of an MLL transcription complex [87]. A possible function of LSD1 is to counteract MLL and keep a balanced H3K4 methylation (Fig. 4a). Of interest is that LSD1 has recently been found to be required for leukemia stem cells transformed with MLL-AF9 [88]. LSD1 knockdown abrogated the transforming ability of MLL-AF9, increased the H3K4me2 levels at MLL-AF9 target gene loci, and reduced the expression of HoxA9 and Meis1. Presumably, LSD1 inhibition could counteract the loss of the SET domain in MLL-AF9 and restore a balanced H3K4 methylation. Pharmacological inhibition of LSD1 showed similar activities against MLL-AF9 leukemia in vitro and in vivo [88]. Although there is a safety concern of LSD1 inhibition $[89,90]$ because of LSD1's role in hematopoiesis $[86,91]$, a recent study showed after termination of LSD1 conditional knockout the impaired hematopoiesis can be recovered in a mouse model [91]. These lines of evidence strongly support that LSD1 is a drug target for MLL leukemia.
In addition, H3K9 and other proteins have been found to be LSD1's substrates [92-96]. In the context of androgen receptor-mediated gene expression, histone $\mathrm{H} 3$ threonine 6 is phosphorylated by PKC $\beta 1$, which prevents LSD1 from binding to methylated H3K4. In complex with androgen receptor and PKC $\beta 1$, LSD1 can change its substrate-specificity and demethylate $\mathrm{H} 3 \mathrm{~K} 9 \mathrm{mel}$ and 2 [92]. DNA methyltransferase 1 (DNMT1), which maintains the integrity of DNA methylation as well as plays an important role in maintaining hematopoietic stem and progenitor cells [97], is also a substrate of LSD1. DNMT1 is methylated in vivo and such methylation destabilizes the protein. LSD1 can demethylate and therefore stabilize DNMT1. Therefore, LSD1 is of importance in maintaining global DNA methylation [93]. In addition, LSD1 can demethylate other non-histone proteins, such as p53 [94], MYPT1 [95], and STAT3 [96], and regulate gene expression mediated by these proteins.

Overexpression of LSD1 has been found in many types of cancer [98-102], including AML (without an MLLtranslocation), lung, breast, and prostate cancer. These observations implicate that LSD1 is a potential drug target for these tumors. It was recently found that a significant portion of cell lines of AML and small cell lung cancer (SCLC) are highly sensitive to pharmacological inhibition of LSD1 [103]. Although except for MLLrearranged leukemia, the molecular mechanisms that link LSD1 to these malignancies are not fully understood (likely because LSD1 has multiple protein substrates), inhibition of LSD1 generally caused broad gene expression pattern changes in these sensitive tumors, which could be responsible for the anti-proliferative activity and other effects, e.g., inducing apoptosis and/or differentiation.

\section{LSD1 inhibitors and their biological activities}

A number of small molecule inhibitors of LSD1 have been discovered, developed, reported in the journals and patents [103-112] and reviewed recently [16, 113]. These compounds can be classified into reversible and irreversible inhibitors depending upon their modes of action. We focus on the biological activities of the most potent compounds. Figure 6 summarizes representative inhibitors of these two classes, together with their enzyme and cellular activities. LSD1 belongs to a family of monoamine oxidases (MAO), using FAD as the cofactor for the redox reaction (Fig. 2a). The common feature for irreversible LSD1 inhibitors is that upon oxidation, part of the molecules is able to covalently bind to FAD and permanently deactivates the enzyme [22]. However, for reversible inhibitors, there is no covalent interaction between the inhibitor and the protein.

The first inhibitors of LSD1 with a common cyclopropylamine core structure were derived from Tranylcypromine (7, Fig. 6), an FDA-approved antidepression drug. 


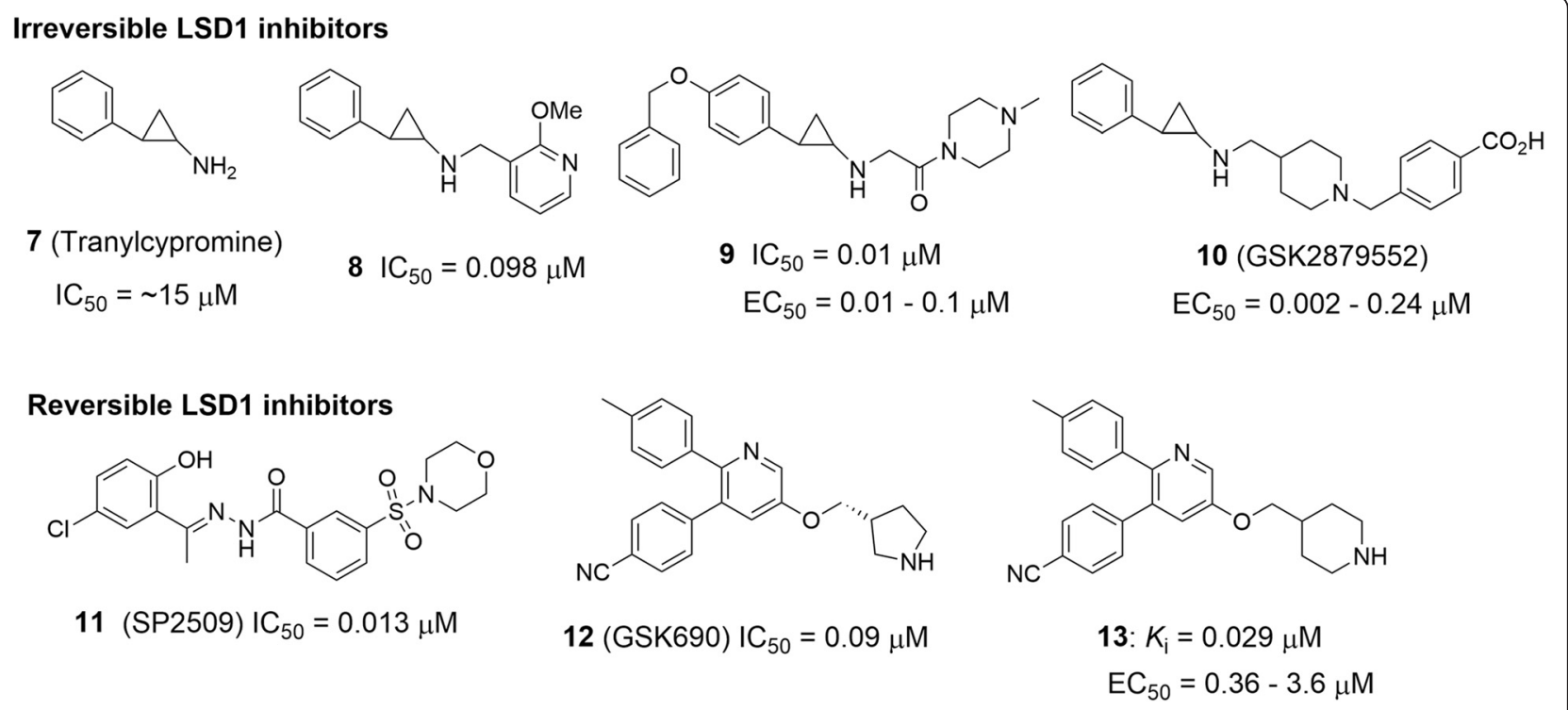

Fig. 6 Structures and activities of representative LSD1 inhibitors

Compound 7 is an inhibitor of MAO-A and - $\mathrm{B}$, enzymes that degrade neurotransmitters in the central nervous system. Compound 7 weakly inhibits LSD1 with an $\mathrm{IC}_{50}$ of $\sim 15 \mu \mathrm{M}$. More potent inhibitors have been developed based on the structure of 7 . Of importance for the inhibitor optimization is the introduction of a second amine-containing $\mathrm{N}$-substituent, such as those on the right side of cyclopropylamine moiety in highly potent LSD1 inhibitors $8-10$. These basic groups not only greatly increase the inhibitory activity, but also render excellent LSD1 selectivity against MAO-A and -B [112]. Compound 8 (compound B in [88]) inhibited recombinant LSD1 in vitro with an $\mathrm{IC}_{50}$ of $98 \mathrm{nM}$. It showed antitumor activities against MLL-AF9 transformed leukemic stem cells. It inhibited colony-forming ability of MLLAF9 containing leukemia cells with $\mathrm{EC}_{50}$ values as low as $50 \mathrm{nM}$. It also down-regulated expression of many leukemia-relevant genes such as HoxA7, HoxA9 and Meis1. However, it exhibited somewhat severe toxicities in a mouse model of MLL-AF9 leukemia, causing deaths of many experimental mice presumably due to insufficient inhibitory potency and/or inappropriate dosages. Compound 9 (compound 1 in [111]) is a much more potent LSD1 inhibitor, almost quantitatively deactivating the enzyme with an $\mathrm{IC}_{50}$ of $9.8 \mathrm{nM}$. It exhibited potent antiproliferative activity against MLL-rearranged leukemia cell lines MV4-11 and Molm-13 with $\mathrm{EC}_{50}$ values of 10 and $96 \mathrm{nM}$, while 9 is almost inactive against leukemia cells NB4 and U937 without an MLL-translocation. The differential activities of compound 9 (as well as several other LSD1 inhibitors) suggest that the LSD1 inhibitor is noncytotoxic, but LSD1 is essential for MLL-rearranged leukemia cells. In vivo antitumor studies using a systemic murine model of MV4-11 leukemia showed that compound 9 did not exhibit overt toxicities and was able to inhibit leukemia progression by $>90 \%$ and significantly prolong survival of the experimental animals. Another potent LSD1 inhibitor GSK2879552 (10) was found to exhibit high anti-proliferative activity against 20 out of 29 AML cell lines with $\mathrm{EC}_{50}$ values ranging from $\sim 3-100 \mathrm{nM}$ [103]. In addition, anti-proliferation screening of compound 10 led to the finding that a significant portion (9 out of 28) of small cell lung carcinoma (SCLC) cell lines were susceptible to 10 with $\mathrm{EC}_{50} \mathrm{~s}$ of $\sim 2-240 \mathrm{nM}$. This compound also showed significant antitumor activity in a mouse xenograft model of SCLC cancer. Similarly, compound $\mathbf{1 0}$ is also devoid of general cytotoxicity: it did not inhibit the growth of $>100$ cell lines across a range of cancer types, showing a high selectivity of using LSD1 inhibitors targeting cancer. Mechanistic studies showed that gene expression of TGF- $\beta$ signaling, which is dysregulated in SCLC, was significantly altered upon treatment with compound 10. This could be attributed to the antitumor activity of the LSD1 inhibitor. In addition, DNA hypomethylation of a gene set was identified to be correlated with the sensitivity of SCLC cells (including primary patient samples) to LSD1 inhibition [105]. This biomarker could be used as a major criterion for patient recruitment. Compound 10 has currently been in clinical trials for SCLC, while no clinical data have been disclosed.

Several chemo-types of reversible LSD1 inhibitors have been disclosed, among which compounds SP2509 (11) [107], GSK690 (12) [16], and 13 (compound 17 in [112]) possess low $\mathrm{nM}$ in vitro inhibitory activity. Compound 11 potently inhibited LSD1 with an $\mathrm{IC}_{50}$ of $13 \mathrm{nM}$, showing a non-competitive mode of action. Treatment 
with 11 increased promoter-specific H3K4 methylation, inhibited colony-formation, and induced differentiation and apoptosis of several AML cell lines including MV411, Molm-13, and OCI-AML3. The combination of 11 with an inhibitor of HDAC exhibited synergy and showed significantly improved in vivo antileukemia activity in mouse models of AML [107]. Compounds 12 and 13 are quite similar, with the same 3-, 5-, 6-trisubstituted pyridine core structure. Preliminary biological data of compound 12 were presented in the 2013 American Association of Cancer Research annual meeting, showing $90 \mathrm{nM} \mathrm{IC} \mathrm{I}_{50}$ against LSD1, high enzyme selectivity, as well as low $\mu \mathrm{M}$ cellular activity against AML cells. Compound 13 showed an improved in vitro inhibitory activity $(29 \mathrm{nM})$ against LSD1 as well as good anti-proliferative activities $\left(\mathrm{EC}_{50}\right.$ : $0.36-3.6 \mu \mathrm{M})$ against several sensitive cancer cells including MV4-11 with MLL-AF4 oncogene [112].

\section{MLL inhibitors}

In MLL-rearranged leukemia, the MLL gene translocation is heterozygous. The H3K4 methyltransferase activity of the remaining copy of WT MLL was found to be essential for the malignancy [92]. Therefore, MLL inhibitors could be useful to treat MLL-rearranged leukemia. However, compounds that directly inhibit the SET domain of MLL have not been reported. Alternatively, the MLL SET domain alone was found to have extremely low methyltransferase activity $[114,115]$. The optimal enzyme activity requires its complexation with three other proteins, i.e., WDR5, ASH2L, and RbBP5. Among these, the interaction between WDR5 and MLL is critical, which led to the finding of indirect MLL inhibitors, compounds that disrupt the binding of WDR5 to MLL $[116,117]$. Several compounds have recently been found to bind to WDR5 with $K_{\mathrm{d}}$ values of $<0.001-5.5 \mu \mathrm{M}$. To date, the best compound MM-401 (14, Fig. 7), an extremely tight binder to WDR5 with a $K_{\mathrm{d}}$ value of $<1 \mathrm{nM}$, showed an $\mathrm{IC}_{50}$ of $0.9 \mathrm{nM}$ in disrupting the interaction between WDR5 and MLL. Indeed, compound 14 almost quantitatively inhibited the methyltransferase activity of the MLL complex $(0.5 \mu \mathrm{M})$ with an $\mathrm{IC}_{50}$ value of $0.32 \mu \mathrm{M}$ in vitro. Because the WDR5-MLL interaction is unique, compound 14 exhibited a high enzyme selectivity profile: it did not inhibit several closely related SET domain methyltransferases including MLL2 - 4, SET1, and SET7/9. Consistent with MLL's role, it showed selective activity against MLL-rearranged leukemia cells. Compound 14 inhibited the proliferation of MLLrearranged leukemia cells with $\mathrm{EC}_{50}$ values of $12-$ $30 \mu \mathrm{M}$, while it had no effects on other non-MLL leukemia cells. The relatively weak cellular activity might be due to the poor cell permeability of compound 14, a cyclic peptidomimetic compound.

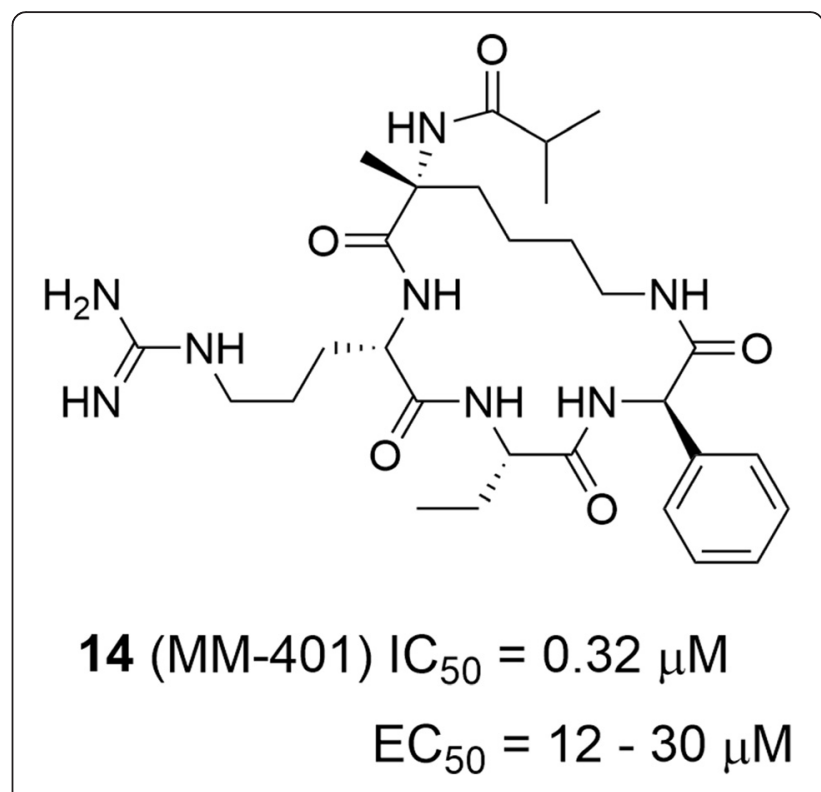

Fig. 7 Structure and activity of a compound that disrupts MLL:WDR5 interactions and thereby inhibits MLL indirectly

\section{H3K27 methyltransferase EZH2}

H3K27 methylation and EZH2 in health and cancer

SET domain containing EZH2 (Enhancer-of-zeste homo$\log 2$ ) and its close homolog EZH1 catalyze mono-, diand tri-methylation of H3K27 [118-120]. EZH2 was originally identified as a member protein of the Polycomb Repressive Complex 2 (PRC2), which functions as a transcription repressor of Hox gene clusters important to the development [121-123]. In 2002, it was further determined to be a methyltransferase of H3K27 [118120]. EZH2 alone is not catalytically active. Complexation with EED and SUZ12, two other members in PRC2, is required to methylate H3K27 [124, 125]. The biology of EZH2-containing PRC2 as well as their mediated H3K27 methylation has been reviewed [121-123, 126]. Briefly, EZH2 is essential for embryonic development and plays important roles in normal physiology. EZH2 mediated H3K27me3 has been found to be a "histone code" for transcription repression, while the genes silenced by EZH2/H3K27me3 are different, depending upon cell types [127]. Such epigenetic transcription repression is essential to cell fate determination and function. However, the underlying regulatory mechanism for the gene silencing is complicated and not fully understood. Other proteins in the PRC2 complex also contribute to the gene silencing. For example, studies showed that DNMT is associated with EZH2 in PRC2 and EZH2 is required to recruit DNMT to its target gene promoters and methylate the DNA [128]. This finding showed the two epigenetic events, i.e., H3K27me3 and DNA methylation, are interconnected for transcription repression. In addition, although the homologous EZH1 
also catalyzes H3K27 methylation as well as associates with PRC2, it has different biological functions and cannot substitute EZH2 [129].

Overexpression of EZH2 is often found in a variety of cancers such as breast, prostate, lung and blood cancers [130-135], with its expression level correlated with that of H3K27me3, more virulent progression of the disease, and poor prognosis. Further studies suggested that EZH2 plays important roles in tumorigenesis, progression as well as metastasis $[136,137]$. However, it remains to be answered in these cases whether the methyltransferase activity of EZH2 is required for these cancers. Using potent and selective EZH2 inhibitors, studies have recently shown that proliferation of several types of cancer cells was not significantly affected by pharmacological inhibition of EZH2/H3K27 methylation [78, 138, 139].

Recently, somatic mutations of EZH2 at Y641, and A677 were identified in 12-25\% non-Hodgkin lymphomas [140-142]. Biochemical investigation revealed that these EHZ2 mutants exhibit a different substrate-specificity from that of the WT enzyme [143-145]. The WT EZH2 catalyzes the mono-methylation of H3K27 with the highest speed, while it is significantly less efficient for the second and especially third methylation of H3K27. A reversed trend was observed for the Y641 mutant proteins: they are inactive for the first methylation, but these mutants transfer the second and third methyl to H3K27 in an increasing catalytic efficiency. In addition, the A677G mutant EZH2 can catalyze all three methylation at a high speed. Clinically, these EZH2 mutated lymphomas exhibit a particularly high levels of H3K27me3.

\section{EZH2 inhibitors}

Recent high-throughput screening campaigns followed by medicinal chemistry have identified several potent and highly selective inhibitors of EZH2, as representatively shown in Fig. 8. GSK126 (15) is the first disclosed inhibitor with a $K_{\mathrm{i}}$ value of $0.5-3 \mathrm{nM}$ against WT and all mutant EZH2 enzymes [139]. It showed $>150$-fold selectivity against EZH1 $\left(K_{\mathrm{i}}=89 \mathrm{nM}\right)$, as well as $>1000$ fold selectivity against other HMTs. Enzyme kinetics studies suggested that compound 15 is competitive with the enzyme cofactor SAM and non-competitive with the substrate H3K27. It can potently inhibit cellular H3K27me3 levels with $\mathrm{IC}_{50}$ values of 7-252 $\mathrm{nM}$ in a broad variety of cell lines, independent upon the status of EZH2 mutation. Compound 15 was found to have strong anti-proliferative activities $\left(\mathrm{EC}_{50}=28-861 \mathrm{nM}\right)$ against diffuse large B-cell lymphoma cells containing an EZH2 activating mutation, while lymphoma cells without an EZH2 mutation are generally insensitive. The antitumor activity has also been confirmed in a mouse model study. Treatment with compound 15 was able to cause the xenograft tumors to regress in a dose-dependent manner and significantly prolong the survivals of the tumor bearing mice. Mechanistically, treatment with compound 15 reduced the cellular

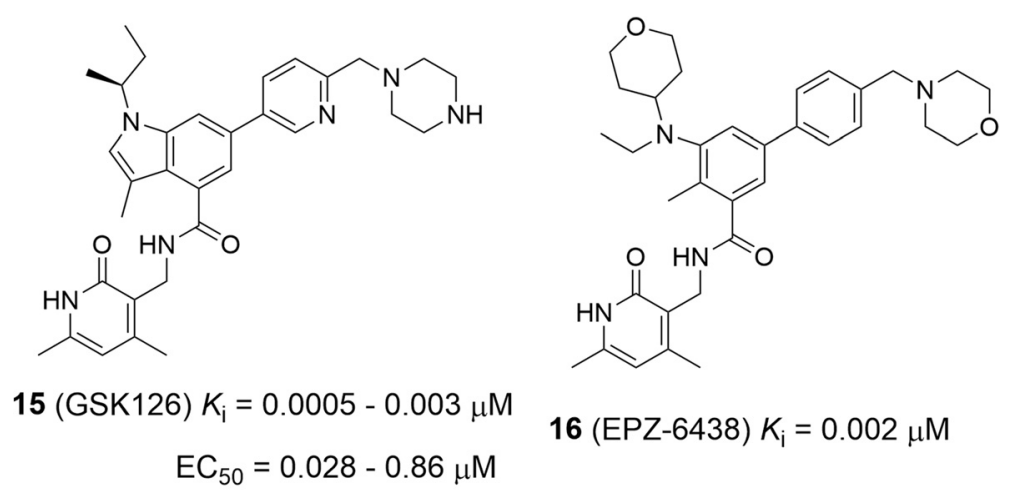<smiles>CCS(=O)(=O)N1CCC([C@@H](C)n2c(C)c(C(=O)NCc3c(OC)cc(C)[nH]c3=O)c3ccccc32)CC1</smiles>

$17(\mathrm{CPI}-169) K_{\mathrm{i}}=0.002 \mu \mathrm{M}$

Fig. 8 Structures and activities of representative EZH2 inhibitors 
H3K27me3 levels and caused a broad range of transcriptional activation of EZH2/PRC2 target genes in sensitive lymphoma cells, while it did not significantly affect the gene expression patterns of insensitive cells.

Scientists from several other institutes have also reported their potent EZH2 inhibitors with enzyme $\mathrm{IC}_{50}$ values in the very low $\mathrm{nM}$ range [138, 146-149], as shown representatively in Fig. 8. Most of these potent EZH2 inhibitors contain the same or similar N-(2-pyridinone-3-yl)methyl amide substructure, suggesting this moiety is important for protein binding. Enzyme kinetics studies showed that these compounds exhibited a competitive mode of action against the cofactor SAM, suggesting that these compounds bind to the SAM-binding site in EZH2. However, no X-ray structures of EZH2inhibitor complexes have been reported to date. The exact binding modes of these compounds still need to be explored, which could provide useful structural information for further rational inhibitor design targeting EZH2. Recently, EZH2 inhibitors 16 and CPI-1205 (with an undisclosed structure) have entered clinical trials against EZH2 mutated non-Hodgkin lymphomas, while the results have not been disclosed.

\section{Isocitrate dehydrogenase (IDH) mutation and histone methylation}

\section{IDH mutation in glioma and other cancers}

Isocitrate dehydrogenase (IDH) is one of the key enzymes in the tricarboxylic acid cycle for aerobic metabolism of glucose [150]. There are three IDH isozymes in humans, with IDH1 located in cytoplasm and IDH2 and 3 in mitochondria [151]. Recent genetic studies have identified recurrent mutations of IDH in a number of cancers. IDH1 mutations were found in 75\% low-grade gliomas as well as secondary glioblastoma multiforme (GBM), the grade IV glioma developed from the low-grade tumors [152-156]. Of particular interest is that all these mutations occur exclusively in the R132 residue of IDH1 or the corresponding R172 residue of IDH2, with the $\mathrm{R} 132 \mathrm{H}$ mutation being predominant (>90\%) in these gliomas. Mutations of IDH1 or 2 have also been found in $20 \%$ AML and several subtypes of sarcomas [157-160]. The IDH mutations occur at an early stage of these cancers, suggesting they could play an important role in oncogenesis [161-163].

Biochemically, although mutant and WT IDH enzymes do not directly work on histones, the products of their catalyzed reactions are an inhibitor or cofactor of JmjC domain histone demethylases (Fig. 2c) and therefore affect histone lysine methylation. As shown in Fig. 9a, WT IDH catalyzes the oxidative decarboxylation of isocitric acid to produce $\alpha$-ketoglutaric acid $(\alpha-K G)$ [150], while mutant IDH enzymes lose this function $[164,165]$. Rather, all these mutants catalyze a new reaction, the reduction of $\alpha$-KG to $D$-2-hydroxyglutaric acid (D2HG) (Fig. 9b) [157, 164, 166]. This new function generates $>100$-fold elevated concentrations of D2HG in tumor cells bearing an IDH1 or IDH2 mutation, while there is only trace amount of D2HG in normal cells. The extremely high level of D2HG is therefore a hallmark of IDH mutated glioma and is suggested to be used as a biomarker for these types of cancers [157, 164, 166]. D2HG with its structure being very similar to $\alpha-K G$ has been found to inhibit $\alpha$-KG-dependent KDMs and TET family of 5-methylcytosine hydroxylases [159, 167], which are important enzymes to maintain a balanced methylation status of histone and DNA. IDH mutated cancers exhibited genome-wide hypermethylation of histone and DNA [159, 167-169]. In addition, transfection of IDH1 R132H mutation into U87 GBM cells without an IDH mutation blocked cell differentiation and also caused DNA/histone hypermethylation in a very similar fashion to that observed in the clinical tumor samples [168, 170]. These lines of evidence strongly support IDH mutation is a drug target for intervention.

\section{Inhibitors of mutant IDH}

Significant efforts from the academia and pharmaceutical industry have been given to discover small molecule inhibitors of mutant IDH. A number of potent and selective inhibitors of mutant IDH1 and 2 with several chemo-types have been published [171-177] and Fig. 9c summarizes several representative compounds together with their biological activities.

AGI-5198 (18) and AGI-6780 (19) with distinct chemical structures were the first inhibitors of mutant IDH1 and IDH2, respectively [172, 173]. Dipeptide-like compound 18 exhibited potent inhibitory activity against $\mathrm{IDH} 1 \mathrm{R} 132 \mathrm{H}\left(\mathrm{IC}_{50}=70 \mathrm{nM}\right)$ and $\mathrm{R} 132 \mathrm{C}\left(\mathrm{IC}_{50}=160 \mathrm{nM}\right)$ mutants, respectively, while it did not inhibit WT IDH1 or WT and mutant IDH2 enzymes $\left(\mathrm{IC}_{50}>100 \mu \mathrm{M}\right)$. This compound can also reduce cellular D2HG concentrations and the colony-forming ability of glioma cells with IDH1 $\mathrm{R} 132 \mathrm{H}$ mutation. Because of the reduced cellular D2HG as well as restored activity of histone demethylases, H3K9 methylation, a repressive histone mark, was found to be decreased globally as well as in several gene promoters. Compound 18 exhibited in vivo antitumor activity in a mouse xenograft model of IDH1 mutated glioma. Compound 19 is a urea-substituted benzenesulfamide compound, showing selective activity against various mutant forms of IDH2 with $\mathrm{IC}_{50}$ values of $4-170 \mathrm{nM}$, while it exhibited high selectivity against WT IDH2 or IDH1 enzymes. It can similarly reduce cellular D2HG concentrations effectively, inhibit proliferation and colony-forming ability, and promote differentiation of primary AML cells harboring an IDH2 mutation. Compounds 20-22 were reported as potent and selective inhibitors of mutant IDH1, 

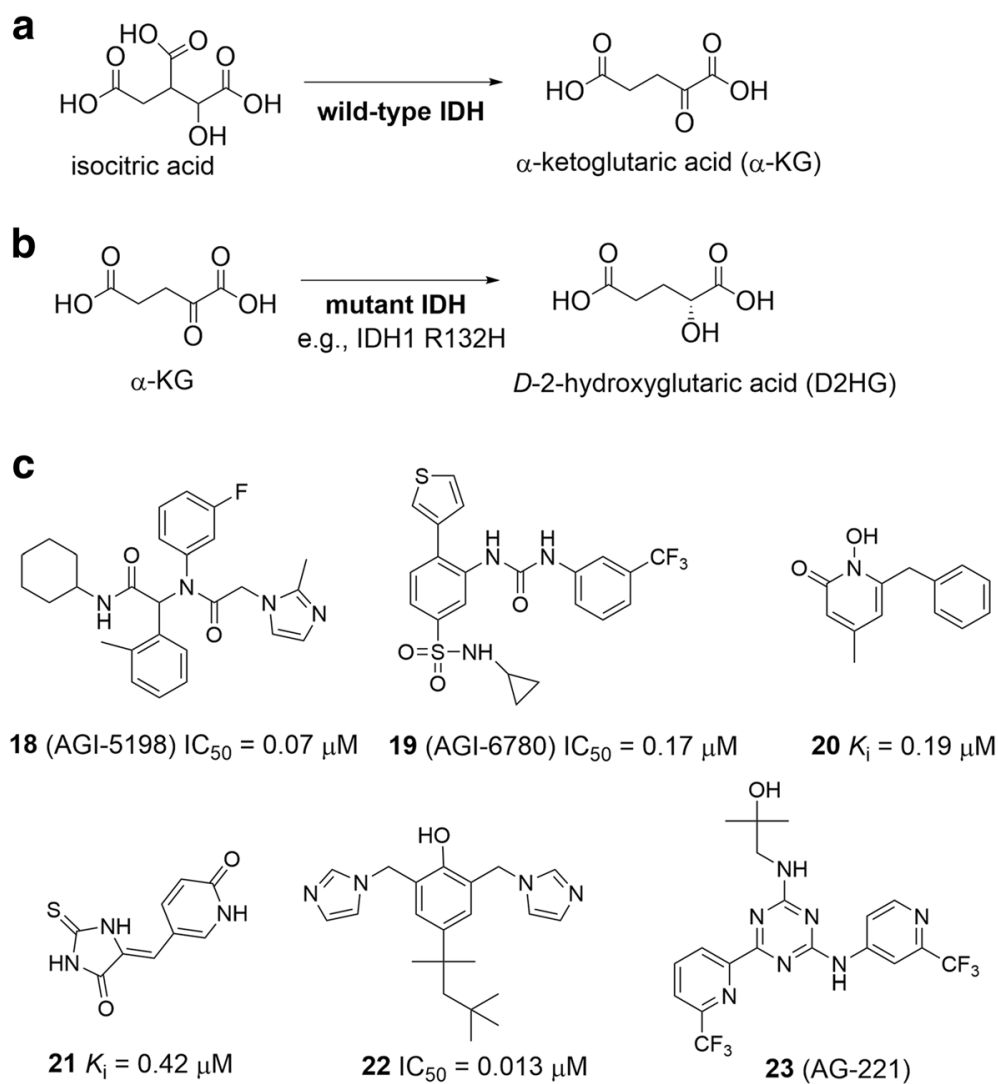

$20 K_{\mathrm{i}}=0.19 \mu \mathrm{M}$

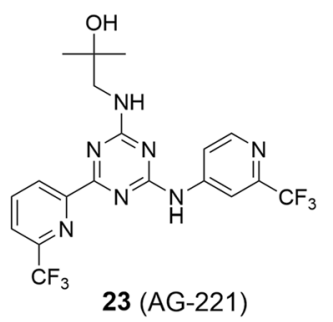

Fig. 9 Mechanisms and inhibitors of IDH. a Mechanism of catalysis for the wild-type IDH. b Mechanism of catalysis for mutant IDHs. c Structures and activities of representative inhibitors of mutant IDH

showing 0.013-0.42 $\mu \mathrm{M}$ inhibitory activities [174-177]. Compounds 21 and 22 can also selectively impair colonyforming ability of patient derived glioma cells having R132H IDH1 mutation.

AG-221 (23), an advanced inhibitor of mutant IDH2, has been in phase I clinical trials against AML or myelodysplastic syndrome with IDH2 mutations. Based on data disclosed in the company's press releases (www. agios.com), compound 23 exhibited promising clinical pharmacokinetic, safety and efficacy profiles. A total of 177 patients, who have relapsed or refractory AML with IDH2 mutations, have been treated with various doses of compound 23. The drug seems to be well tolerated, with the majority of adverse effects being mild to moderate, including nausea, fatigue, increased blood bilirubin and diarrhea. The maximum tolerated dose of 23 has not been reached. Preliminary pharmacokinetic and pharmacodynamics studies showed compound 23 has an excellent oral availability, and a high plasma half-life of $>40 \mathrm{~h}$. Objective responses have been observed for 63 patients out of 158 evaluable patients, showing an overall response rate of $40 \%$. Among these, there were 26 cases of complete remission (CR), three cases of CR with incomplete platelet recovery, 14 cases of marrow $\mathrm{CR}$, two cases of $\mathrm{CR}$ with incomplete hematological recovery as well as 18 cases of partial remission. Given these promising clinical data, more clinical evaluations of compound 23 as well as several other inhibitors of mutant IDH are currently on-going worldwide.

\section{Inhibitors of selected other histone methylation enzymes}

There are excellent review articles that summarize the biology of HKMTs, PRMTs and KDMs as well as their relevance to cancer or other diseases $[4,8,15-17,178]$. As compared to the large number $(>100)$ of these histone methylation enzymes, relatively fewer number of potent and selective small molecule inhibitors have been discovered in the past few years. We describe below potent inhibitors of several other important histone methylation modifying enzymes (Fig. 10). Most of these compounds are cell permeable and can be used as chemical probes for biological studies of these proteins. However, a number of previously reported inhibitors are not included, because of low potency (e.g., with $\mu \mathrm{M}$ enzyme $\mathrm{IC}_{50} \mathrm{~s}$ ), non-specificity, or unknown mechanism of action. It is therefore unclear whether the observed biological 


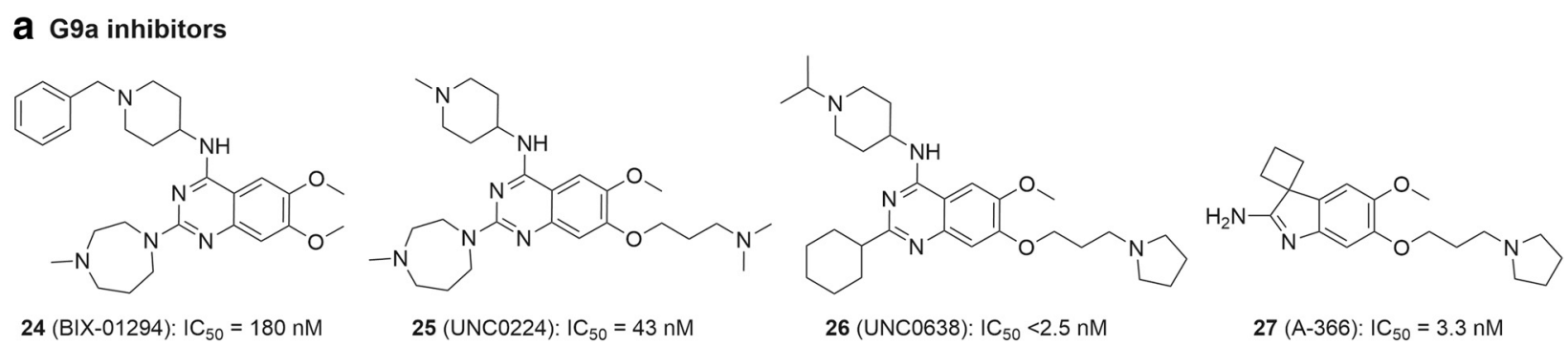

\section{b SMYD2 inhibitors}<smiles>O=C1COc2c(CCNCCN(C(=O)CCNCCc3ccc(Cl)c(Cl)c3)C3CCCCC3)ccc(O)c2N1</smiles><smiles>Cc1cn(CCN2CCN(c3ccccc3-c3cc(C#N)cc(C(=O)NCCCN4CCCC4)c3)CC2)c2ccccc12</smiles>

29 (LLY-507): IC ${ }_{50}<15 \mathrm{nM}$

\section{PRMT inhibitors}<smiles>CNCCN1CCC(c2ccc3[nH]c(-c4ccccc4OC)c(F)c3c2)CC1</smiles>

30 (CMPD-1): $\mathrm{IC}_{50}=30 \mathrm{nM}$<smiles>O=C(CNC(=O)N1CCCC1)Nc1ccc2cnccc2c1</smiles>

31 (SGC707): IC $50=31 \mathrm{nM}$

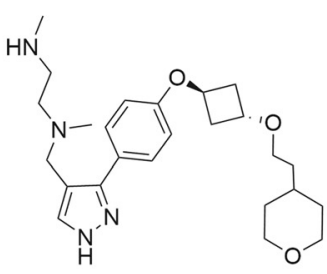

32 (EPZ020411): $I C_{50}=10 \mathrm{nM}$

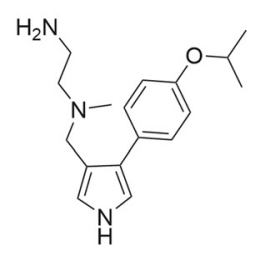

33 (MS023): $\mathrm{IC}_{50}$ as low as $4 \mathrm{nM}$<smiles>O=C(NCC(O)CN1CCc2ccccc2C1)c1cc(NC2COC2)ncn1</smiles>

34 (EPZ015666): IC $50=22 \mathrm{nM}$

D. KDM6 inhibitor

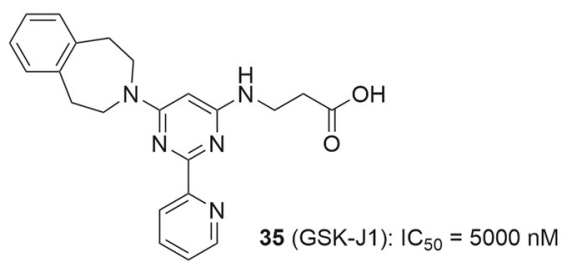

Fig. 10 Structures and activities of representative inhibitors of a G9a/GLP; b SMYD2; c PRMTs; and d KDM6

activities of these compounds are due to inhibition of the protein target or off-target effects.

\section{Inhibitors of other HKMTs}

G9a (also known as EHMT2) and its closely homologous protein GLP (also known as EHMT1) are responsible for mono- and di-methylation of H3K9 [179] and play important roles in gene regulation. There is also strong evidence that G9a/GLP is implicated in several types of cancers [180-182]. The first specific inhibitor of G9a is BIX-01294 (24, Fig. 10a) identified in a high-throughput screening [183]. Compound 24 exhibits an $\mathrm{IC}_{50}$ of 180 nM against $G 9 \alpha$, whereas no inhibition of the other histone methyltransferases, such as SUV39H1 and PRMT1, was observed. In a cellular assay, 24 was found to transiently modulate H3K9me2 marks. Medicinal chemistry modifications based on the scaffold of 24 yielded a series of compounds with improved potency as well as cell permeability, such as UNC0224 (25) [21] and UNC0638 (26) [184]. Compound 25 exhibited an improved IC $_{50}$ of $43 \mathrm{nM}$ against $\mathrm{G} 9 \alpha$ by adding a lysine mimetic group. An X-ray crystal structure of G9a in complex with 25 revealed that this group occupies the lysine binding channel of the protein. Compound 26 is a potent, selective and cell permeable G9a inhibitor, able to reduce H3K9me2 levels in a dose-dependent manner with an $\mathrm{EC}_{50}$ of $81 \mathrm{nM}$. Furthermore, compound 26 can reduce colony-forming ability of breast cancer MCF-7 and MDA-MB231 cells. Compound A-366 (27) with a distinct chemo-type is also a highly potent and selective inhibitor of $\mathrm{G9}$ a with an $\mathrm{IC}_{50}$ of $3.3 \mathrm{nM}$ [185].

SMYD2 is a SET domain-containing methyltransferase with a less restricted substrate-specificity. H3K4 and H3K36 as well as non-histone proteins such as HSP90 
and p53 were found to be a substrate of SMYD2. Because of the observed overexpression in a variety of cancer types [186, 187], it is implicated as a drug target. The first SMYD2 specific inhibitor AZ505 (28, Fig. 10b) was identified in a high-throughput screening, showing an enzyme $\mathrm{IC}_{50}$ of $120 \mathrm{nM}$ as well as selectivity indices of $>690$-fold [188]. The steady-state kinetic studies indicated that this compound is competitive to the peptide substrate and uncompetitive for the cofactor SAM, which was confirmed by an X-ray crystallographic investigation of the SMYD2-28 complex. LLY-507 (29) was disclosed to be a more potent inhibitor of SMYD2 $\left(\mathrm{IC}_{50}\right.$ $<15 \mathrm{nM})$, together with $>100$-fold selectivity over other KMTs [189]. Compound 29 inhibited cellular methylation with an $\mathrm{EC}_{50}$ of $\sim 600 \mathrm{nM}$, showing it is a good chemical probe for investigation of the functions of SMYD2 in normal physiology and diseases.

\section{Inhibitors of PRMTs}

There are two types of PRMTs [9]. The majority of PRMTs (including PRMT1-4, 6, and 8) are the type I enzymes, catalyzing mono- and asymmetric di-methylation of an arginine sidechain. PRMT5 is the only known type II enzyme, catalyzing symmetric di-methylation of an arginine.

CMPD-1 (30, Fig. 10c) is a potent inhibitor of PRMT4 (also known as CARM1) with an enzyme $\mathrm{IC}_{50}$ of $30 \mathrm{nM}$ as well as selectivity indices of $>300$-fold against PRMT1 and 3 [190]. X-ray crystallography showed that compound 30 occupies the substrate-binding pocket and the high selectivity arises from sequence differences between PRMT4 and PRMT1/3.

An allosteric inhibitor SGC707 (31) is a highly potent inhibitor of PRMT3 an $\mathrm{IC}_{50}$ of $31 \mathrm{nM}$ [191]. It exhibited no inhibitory activity against a panel of 27 protein methyltransferases. Crystallographic studies of the PRMT3-31 complex revealed that the inhibitor occupies a cavity $>15 \AA$ from the enzyme active site. In cellular assay, compound 31 was able to reduce H4R3me2 with an $\mathrm{EC}_{50}$ of $225 \mathrm{nM}$.

EPZ020411 (32) has been reported to inhibit PRMT6 with an $\mathrm{IC}_{50}$ of $10 \mathrm{nM}$, while it exhibited good selectivity ( $>10$ fold) against PRMT1 and 8 [192]. In cellular assays, treatment with 32 resulted in a dose-dependent decrease of H3R2me2 with an $\mathrm{EC}_{50}$ of $640 \mathrm{nM}$.

Besides the above selective inhibitors against an individual PRMT enzyme, it is of interest that MS023 (33) is a pan-inhibitor of type I PRMTs [193]. It was designed based on the structures of PRMT4 inhibitor 30 and PRMT6 inhibitor 32. Compound 33 exhibited an enzyme $\mathrm{IC}_{50}$ of $30,119,83,4$, and $5 \mathrm{nM}$ against PRMT1, $3,4,6$, and 8 , respectively. Treatment with 33 significantly decreased levels of H3R2me2 and H4R3me2 with $\mathrm{EC}_{50} \mathrm{~s}$ of 56 and $9 \mathrm{nM}$, respectively.
EPZ015666 (34) was reported as a potent and selective inhibitor of PRMT5 $\left(\mathrm{IC}_{50}=22 \mathrm{nM}\right)$, a type II PRMT [194]. Compound 34 demonstrated potent anti-proliferative activity against mantle cell lymphoma cells Z-138 and Maver-1 ( $\mathrm{EC}_{50}=96$ and $450 \mathrm{nM}$, respectively), because of overexpression of PRMT5 in this type of tumor. It also showed in vivo antitumor activity in xenograft mouse models of these two lymphoma cells.

\section{Inhibitors of other KDMs}

Despite a number of compounds were reported to be inhibitors of the JmjC family of KDMs, they are either analogs of $\alpha-K G$ or metal chelators (e.g., hydroxamates and pyridinyl carboxylates) [16]. These compounds generally lack potent inhibitory activity (mostly having $\mu \mathrm{M} \mathrm{IC}{ }_{50} \mathrm{~s}$ ) and enzyme selectivity. In addition, cellular activities, such as histone methylation changes, anti-proliferation and/or toxicity, of these compounds have not been well investigated. Recently, GSK-J1 (35) was reported to be a selective inhibitor of KDM6, responsible for demethylation of H3K27. Compound 35 was initially identified as a lead in a high-throughput, fluorescence based AlphaScreen assay and later confirmed to selectively inhibit KDM6B with an $\mathrm{IC}_{50}$ of $5 \mu \mathrm{M}$, while it exhibited $\sim 10$-fold selectivity against KDM4 enzymes [195]. X-ray crystallography showed 35 binds to the active site of the protein with two of its $\mathrm{N}$ atoms chelating the metal ion. Compound 35 is not cell permeable, while its ester prodrug GSK-J4 was found to inhibit cellular production of TNF- $\alpha$ with an $\mathrm{EC}_{50}$ of $9 \mu \mathrm{M}$. While the global histone methylation changes were not determined, GSK-J4 inhibited a reduction of the H3K27me3 level at the TNFA gene promoter using chromatin immunoprecipitation (ChIP) assays, suggesting it is on-target in cells.

\section{Perspectives and conclusions}

Histone methylation plays critical roles in gene regulation, cell differentiation, DNA recombination and damage repair. Histone methylation modifying enzymes, which are often part of a transcription complex, have been heavily studied for the past few decades and great amount of understanding has been obtained for their biochemistry, structures and biological functions in normal physiology as well as in pathogenesis. Many of these enzymes have been validated or implicated as drug targets for intervention. Small molecule inhibitors of these proteins are not only potential therapeutics, but also useful chemical probes for investigation of biological functions of histone modifying enzymes. To date, discovery and development of small molecule inhibitors of HMTs and KDMs have been still in a very early stage, with significant efforts and successful stories from the academia and pharmaceutical industry occurring only in the past few years. However, it is exciting that the field 
has been growing exponentially: as described in this review, highly potent and selective inhibitors of several such proteins, including DOT1L, LSD1, EZH2, and mutant IDH, have been developed and undergone extensive preclinical testing. Several compounds have quickly entered and been evaluated in clinical trials in just a few years. They have demonstrated promising clinical safety and efficacy, showing great potentials to become clinically useful drugs. These remarkable outcomes could further attract more scientists to the field and jump-start drug discovery and development endeavors targeting histone methylation for cancer therapy. However, due to important functions of histone methylation in normal physiology, inhibition of histone methylation enzymes could cause toxicities. Vigorous toxicological studies should be performed to ensure there is a sufficient therapeutic window for such pharmacological inhibition.

Additionally, small molecule compounds targeting histone methylation enzymes could provide great opportunities for finding new cancer biology. Given the differences between pharmacological inhibition and genetic knockdown, using these compounds as probes can complement biological means to explore the functions of a histone methylation protein in health and diseases. For example, many of these proteins (e.g., MLL and DOT1L) contains multiple domains having more functions than being a methyltransferase. Pharmacological inhibition of the catalytic domain of the protein, without disturbing the functions of other domains, could provide more useful insight. Moreover, in the context of cancer therapy, overexpression of a certain histone methylation protein is often found in cancer. However, it is still unclear whether the cancer is dependent upon the catalytic activity of such protein. These compounds can be used to validate whether the protein is a real drug target. Many of the inhibitors shown in Figs. 4, 5, 6, 7, 8, 9, and 10 are commercially available for these studies. The availability and costs can be found in PubChem (https:// pubchem.ncbi.nlm.nih.gov/).

There are still a number of challenges in the field from the perspectives of chemistry and biology. From the chemistry side, finding potent and selective small molecule inhibitors is a major challenge, because these enzymes share a relatively high homology and use the same cofactor. This requires an enormous amount of coordinated efforts in high-throughput screening, ligand and structure-based inhibitor design and synthesis, medicinal chemistry as well as biological activity testing. If successful, this is, however, the first step towards yielding a clinically useful drug. Repeated rounds of medicinal chemistry, in vitro and in vivo pharmacokinetics, toxicity and efficacy testing are needed to find suitable drug candidates, which is followed by a low success rate in clinical trials. Very high costs for the whole process represent another barrier. From the biology side, more studies need to be performed to validate whether a histone modifying enzyme is a cancer target. Because of the high costs for high-throughput screening and medicinal chemistry, it is desirable that sufficient evidence showing a critical function of the enzyme has been found in the disease before compound development. Genetic screening of gene mutations in clinical tumor samples represents a powerful means to identify potential candidates (e.g., work in 5.1 and 6.1 for mutations of EZH2 and IDH and [196]). Ensuing biochemical and biological studies are needed to further identify the links between the functions of such mutation and pathogenesis. In addition, determination and comparative analysis of methylation levels at different histone residues (e.g., H3K79me2 in [67]) between normal and patient samples could provide useful hints. If there are available resources, direct screening a collection of specific inhibitors of histone modifying enzymes against a large number of cancer cell lines is also a fruitful measure to find such links (e.g., work in [103]). With the successful stories summarized here, it is envisioned that more histone methylation enzymes can be identified as therapeutic targets for cancer.

Combination therapy is a viable approach to increase the effectiveness of a histone methylation modulator. Because multiple histone modifications that change global gene expression might be involved in a certain type of cancer, combination therapy targeting two or more closely associated epigenetic changes could be synergistic. For example, strong synergy was observed for combination treatment using inhibitors of LSD1 and DOT1L that closely associated in MLL-rearranged leukemia [111]. Synergy was also found for combination therapy of a LSD1 inhibitor with an HDAC inhibitor in vitro and in AML mouse models [107]. Aberrant methylation of DNA and histone are often associated [197-199], combination with a DNA methylation inhibitor could also be useful. To rationally design a synergistic combination therapy, mechanistic studies of oncogenesis at the molecular level are helpful to find two possible candidate proteins for intervention [200]. In addition, combination therapy is useful to overcome drug resistance as well as reduce toxicities and side effects.

\footnotetext{
Abbreviations

AML, acute myeloid leukemia; ALL, acute lymphocytic leukemia; DOT1L, disruptor of telomeric silencing 1 like; D2HG, D-2-hydroxyglutaric acid; DNMT, DNA methyltransferase; EZH2, Enhancer-of-zeste homolog 2; FAD, flavin adenine dinucleotide; H3K4, histone3-lysine4; H3K79, histone3-lysine79; HDAC, histone deacetylases; HMT, histone methyltransferase; HKMT, histone lysine methyltransferase; IDH, isocitrate dehydrogenases; KDM, lysine demethylase; $\mathrm{a}-\mathrm{KG}$, a-ketoglutarate; $\mathrm{MAO}$, monoamine oxidase; $\mathrm{MLL}$, mixed lineage leukemia; LSD1, lysine-specific demethylase 1; PHF, plant homeodomain finger; PRC2, polycomb repressive complex 2; PRMT, protein arginine methyltransferase; SAH, S-adenosylhomocysteine; SAM, S-adenosylmethionine; SET, su(var)3-9, Enhancer-of-zeste, trithorax; WT, wild-type
} 


\section{Funding}

This work was supported by grants (RP140169 and RP150129) from the Cancer Prevention and Research Institute of Texas (CPRIT) and a grant (R01NS080963) from NIH/NINDS to Y.S.

\section{Availability of data and materials} Not applicable.

\section{Authors' contributions}

YS, FW, and JW performed the literature search, wrote the manuscript, and have read and approved the final version.

\section{Competing interests}

The authors declare that they have no competing interests.

\section{Received: 6 April 2016 Accepted: 7 June 2016}

Published online: 17 June 2016

\section{References}

1. Jones PA, Baylin SB. The epigenomics of cancer. Cell. 2007;128(4):683-92

2. Kouzarides T. Chromatin modifications and their function. Cell. 2007;128(4): 693-705.

3. Minucci S, Pelicci PG. Histone deacetylase inhibitors and the promise of epigenetic (and more) treatments for cancer. Nat Rev Cancer. 2006;6(1):38-51.

4. Copeland RA, Solomon ME, Richon VM. Protein methyltransferases as a target class for drug discovery. Nat Rev Drug Discov. 2009:8(9):724-32.

5. Miller TA, Witter DJ, Belvedere S. Histone deacetylase inhibitors. J Med Chem. 2003:46(24):5097-116.

6. Monneret C. Histone deacetylase inhibitors. Eur J Med Chem. 2005;40(1):1-13.

7. Zheng Z, Cheng S, Wu W, Wang L, Zhao Y, Shen Y, et al. c-FLIP is involved in tumor progression of peripheral T-cell lymphoma and targeted by histone deacetylase inhibitors. J Hematol Oncol. 2014;7:88.

8. Bhaumik SR, Smith E, Shilatifard A. Covalent modifications of histones during development and disease pathogenesis. Nat Struct Mol Biol. 2007; 14(11):1008-16

9. Cheng X, Collins RE, Zhang X. Structural and sequence motifs of protein (histone) methylation enzymes. Annu Rev Biophys Biomol Struct. 2005;34:267-94.

10. Schubert $\mathrm{HL}$, Blumenthal RM, Cheng X. Many paths to methyltransfer: a chronicle of convergence. Trends Biochem Sci. 2003;28(6):329-35.

11. Dimitrova $E$, Turberfield AH, Klose RJ. Histone demethylases in chromatin biology and beyond. EMBO Rep. 2015;16(12):1620-39.

12. Hojfeldt JW, Agger K, Helin K. Histone lysine demethylases as targets for anticancer therapy. Nat Rev Drug Discov. 2013;12(12):917-30.

13. Cloos PA, Christensen J, Agger K, Helin K. Erasing the methyl mark: histone demethylases at the center of cellular differentiation and disease. Genes Dev. 2008:22(9):1115-40.

14. Cole PA. Chemical probes for histone-modifying enzymes. Nat Chem Biol. 2008;4(10):590-7.

15. Liu Y, Liu K, Qin S, Xu C, Min J. Epigenetic targets and drug discovery: part 1: histone methylation. Pharmacol Ther. 2014;143(3):275-94.

16. Liu K, Liu Y, Lau JL, Min J. Epigenetic targets and drug discovery Part 2: Histone demethylation and DNA methylation. Pharmacol Ther. 2015;151: $121-40$.

17. McGrath J, Trojer P. Targeting histone lysine methylation in cancer. Pharmacol Ther. 2015;150:1-22.

18. Richon VM, Johnston D, Sneeringer CJ, Jin L, Majer CR, Elliston K, et al. Chemogenetic analysis of human protein methyltransferases. Chem Biol Drug Des. 2011;78(2):199-210.

19. Dillon SC, Zhang X, Trievel RC, Cheng X. The SET-domain protein superfamily: protein lysine methyltransferases. Genome Biol. 2005;6(8):227.

20. Min J, Feng Q, Li Z, Zhang Y, Xu RM. Structure of the catalytic domain of human DOT1L, a non-SET domain nucleosomal histone methyltransferase. Cell. 2003;112(5):711-23.

21. Liu F, Chen X, Allali-Hassani A, Quinn AM, Wasney GA, Dong A, et al. Discovery of a 2,4-diamino-7-aminoalkoxyquinazoline as a potent and selective inhibitor of histone lysine methyltransferase G9a. J Med Chem. 2009;52(24):7950-3.

22. Binda C, Valente S, Romanenghi M, Pilotto S, Cirilli R, Karytinos A, et al. Biochemical, structural, and biological evaluation of tranylcypromine derivatives as inhibitors of histone demethylases LSD1 and LSD2. J Am Chem Soc. 2010;132(19):6827-33.
23. Shi Y, Lan F, Matson C, Mulligan P, Whetstine JR, Cole PA, et al. Histone demethylation mediated by the nuclear amine oxidase homolog LSD1. Cell. 2004;119(7):941-53.

24. Forneris F, Binda C, Adamo A, Battaglioli E, Mattevi A. Structural basis of LSD1-CoREST selectivity in histone H3 recognition. J Biol Chem. 2007; 282(28):20070-4.

25. Pedersen MT, Helin K. Histone demethylases in development and disease. Trends Cell Biol. 2010;20(11):662-71.

26. Maes T, Carceller E, Salas J, Ortega A, Buesa C. Advances in the development of histone lysine demethylase inhibitors. Curr Opin Pharmacol. 2015:23:52-60.

27. Schneider J, Shilatifard A. Histone demethylation by hydroxylation: chemistry in action. ACS Chem Biol. 2006;1(2):75-81.

28. Chen Z, Zang J, Kappler J, Hong X, Crawford F, Wang Q, et al. Structural basis of the recognition of a methylated histone tail by JMJD2A. Proc Natl Acad Sci U S A. 2007;104(26):10818-23.

29. Horton JR, Upadhyay AK, Qi HH, Zhang X, Shi Y, Cheng X. Enzymatic and structural insights for substrate specificity of a family of jumonji histone lysine demethylases. Nat Struct Mol Biol. 2010;17(1):38-43.

30. Singer MS, Kahana A, Wolf AJ, Meisinger LL, Peterson SE, Goggin C, et al. Identification of high-copy disruptors of telomeric silencing in Saccharomyces cerevisiae. Genetics. 1998;150(2):613-32.

31. Feng $\mathrm{Q}$, Wang $\mathrm{H}, \mathrm{Ng} \mathrm{HH}$, Erdjument-Bromage $H$, Tempst $P$, Struhl $K$, et al. Methylation of H3-lysine 79 is mediated by a new family of HMTases without a SET domain. Curr Biol. 2002;12(12):1052-8.

32. Mueller D, Bach C, Zeisig D, Garcia-Cuellar MP, Monroe S, Sreekumar A, et al. A role for the MLL fusion partner ENL in transcriptional elongation and chromatin modification. Blood. 2007:110(13):4445-54.

33. Mueller D, Garcia-Cuellar MP, Bach C, Buhl S, Maethner E, Slany RK. Misguided transcriptional elongation causes mixed lineage leukemia. PLoS Biol. 2009;7(11):e1000249.

34. Bitoun E, Oliver PL, Davies KE. The mixed-lineage leukemia fusion partner AF4 stimulates RNA polymerase II transcriptional elongation and mediates coordinated chromatin remodeling. Hum Mol Genet. 2007:16(1):92-106.

35. Mohan M, Herz HM, Takahashi YH, Lin C, Lai KC, Zhang Y, et al. Linking H3K79 trimethylation to Wnt signaling through a novel Dot1-containing complex (DotCom). Genes Dev. 2010;24(6):574-89.

36. Lin C, Smith ER, Takahashi H, Lai KC, Martin-Brown S, Florens L, et al. AFF4, a component of the ELL/P-TEFb elongation complex and a shared subunit of MLL chimeras, can link transcription elongation to leukemia. Mol Cell. 2010;37(3):429-37.

37. Nguyen AT, Zhang Y. The diverse functions of Dot1 and H3K79 methylation. Genes Dev. 2011;25(13):1345-58.

38. Barry ER, Corry GN, Rasmussen TP. Targeting DOT1L action and interactions in leukemia: the role of DOT1L in transformation and development. Expert Opin Ther Targets. 2010;14(4):405-18.

39. Bernt KM, Armstrong SA. A role for DOT1L in MLL-rearranged leukemias. Epigenomics. 2011;3(6):667-70.

40. Laurenson P, Rine J. Silencers, silencing, and heritable transcriptional states. Microbiol Rev. 1992:56(4):543-60.

41. van Leeuwen F, Gafken PR, Gottschling DE. Dot1p modulates silencing in yeast by methylation of the nucleosome core. Cell. 2002;109(6):745-56.

42. Steger DJ, Lefterova MI, Ying L, Stonestrom AJ, Schupp M, Zhuo D, et al. DOT1L/KMT4 recruitment and H3K79 methylation are ubiquitously coupled with gene transcription in mammalian cells. Mol Cell Biol. 2008;28(8):2825-39.

43. Wang Z, Zang C, Rosenfeld JA, Schones DE, Barski A, Cuddapah S, et al. Combinatorial patterns of histone acetylations and methylations in the human genome. Nat Genet. 2008;40(7):897-903.

44. Shanower GA, Muller M, Blanton JL, Honti V, Gyurkovics H, Schedl P. Characterization of the grappa gene, the Drosophila histone $\mathrm{H} 3$ lysine 79 methyltransferase. Genetics. 2005;169(1):173-84.

45. Ooga M, Inoue A, Kageyama S, Akiyama T, Nagata M, Aoki F. Changes in H3K79 methylation during preimplantation development in mice. Biol Reprod. 2008;78(3):413-24.

46. Jones B, Su H, Bhat A, Lei H, Bajko J, Hevi S, et al. The histone H3K79 methyltransferase Dot $1 \mathrm{~L}$ is essential for mammalian development and heterochromatin structure. PLoS Genet. 2008:4(9):e1000190.

47. Nguyen AT, He J, Taranova O, Zhang Y. Essential role of DOT1L in maintaining normal adult hematopoiesis. Cell Res. 2011;21(9):1370-3.

48. Feng Y, Yang Y, Ortega MM, Copeland JN, Zhang M, Jacob JB, et al. Early mammalian erythropoiesis requires the Dot $1 \mathrm{~L}$ methyltransferase. Blood. 2010;116(22):4483-91. 
49. Nguyen AT, Xiao B, Neppl RL, Kallin EM, Li J, Chen T, et al. DOT1L regulates dystrophin expression and is critical for cardiac function. Genes Dev. 2011; 25(3):263-74.

50. Reisenauer MR, Wang SW, Xia Y, Zhang W. Dot1a contains three nuclear localization signals and regulates the epithelial $\mathrm{Na}+$ channel $(\mathrm{ENaC})$ at multiple levels. Am J Physiol Renal Physiol. 2010;299(1):F63-76.

51. Zhang W, Xia X, Reisenauer MR, Hemenway CS, Kone BC. Dot1a-AF9 complex mediates histone H3 Lys-79 hypermethylation and repression of ENaCalpha in an aldosterone-sensitive manner. J Biol Chem. 2006;281(26): 18059-68.

52. Krivtsov AV, Armstrong SA. MLL translocations, histone modifications and leukaemia stem-cell development. Nature reviews. 2007;7(11):823-33.

53. Daser A, Rabbitts TH. The versatile mixed lineage leukaemia gene MLL and its many associations in leukaemogenesis. Semin Cancer Biol. 2005;15(3):175-88.

54. Liedtke M, Cleary ML. Therapeutic targeting of MLL. Blood. 2009;113(24): 6061-8.

55. Hilden JM, Dinndorf PA, Meerbaum SO, Sather H, Villaluna D, Heerema NA et al. Analysis of prognostic factors of acute lymphoblastic leukemia in infants: report on CCG 1953 from the Children's Oncology Group. Blood. 2006;108(2):441-51.

56. Chen CS, Sorensen PH, Domer PH, Reaman GH, Korsmeyer SJ, Heerema NA, et al. Molecular rearrangements on chromosome 11q23 predominate in infant acute lymphoblastic leukemia and are associated with specific biologic variables and poor outcome. Blood. 1993;81(9):2386-93.

57. Felix CA, Hosler MR, Winick NJ, Masterson M, Wilson AE, Lange BJ. ALL-1 gene rearrangements in DNA topoisomerase II inhibitor-related leukemia in children. Blood. 1995;85(11):3250-6.

58. Mrozek K, Heinonen K, Lawrence D, Carroll AJ, Koduru PR, Rao KW, et al. Adult patients with de novo acute myeloid leukemia and t(9; 11)(p22; q23) have a superior outcome to patients with other translocations involving band 11q23: a cancer and leukemia group B study. Blood. 1997;90(11):4532-8.

59. Ross ME, Mahfouz R, Onciu M, Liu H-C, Zhou X, Song G, et al. Gene expression profiling of pediatric acute myelogenous leukemia. Blood. 2004; 104(12):3679-87.

60. Gu Y, Nakamura T, Alder H, Prasad R, Canaani O, Cimino G, et al. The t(4;11) chromosome translocation of human acute leukemias fuses the ALL-1 gene, related to Drosophila trithorax, to the AF-4 gene. Cell. 1992;71(4):701-8.

61. Tkachuk DC, Kohler S, Cleary ML. Involvement of a homolog of Drosophila trithorax by 11q23 chromosomal translocations in acute leukemias. Cell. 1992;71(4):691-700.

62. Butler LH, Slany R, Cui X, Cleary ML, Mason DY. The HRX proto-oncogene product is widely expressed in human tissues and localizes to nuclear structures. Blood. 1997;89(9):3361-70.

63. Briggs SD, Bryk M, Strahl BD, Cheung WL, Davie JK, Dent SY, et al. Histone H3 lysine 4 methylation is mediated by Set1 and required for cell growth and rDNA silencing in Saccharomyces cerevisiae. Genes Dev. 2001;15(24):3286-95.

64. Milne TA, Briggs SD, Brock HW, Martin ME, Gibbs D, Allis CD, et al. MLL targets SET domain methyltransferase activity to Hox gene promoters. Mol Cell. 2002;10(5):1107-17.

65. Ayton PM, Cleary ML. Molecular mechanisms of leukemogenesis mediated by MLL fusion proteins. Oncogene. 2001;20(40):5695-707.

66. Okada $Y$, Feng $Q$, Lin $Y$, Jiang $Q$, Li Y, Coffield VM, et al. hDOT1L links histone methylation to leukemogenesis. Cell. 2005;121(2):167-78.

67. Krivtsov AV, Feng Z, Lemieux ME, Faber J, Vempati S, Sinha AU, et al. H3K79 methylation profiles define murine and human MLL-AF4 leukemias. Cancer Cell. 2008;14(5):355-68.

68. Daigle SR, Olhava EJ, Therkelsen CA, Majer CR, Sneeringer CJ, Song J, et al. Selective killing of mixed lineage leukemia cells by a potent small-molecule DOT1L inhibitor. Cancer Cell. 2011;20(1):53-65.

69. Basavapathruni A, Jin L, Daigle SR, Majer CR, Therkelsen CA, Wigle TJ, et al. Conformational adaptation drives potent, selective and durable inhibition of the human protein methyltransferase DOT1L. Chem Biol Drug Des. 2012;80(6):971-80.

70. Anglin JL, Deng L, Yao Y, Cai G, Liu Z, Jiang H, et al. Synthesis and structureactivity relationship investigation of adenosine-containing inhibitors of histone methyltransferase DOT1L. J Med Chem. 2012;55(18):8066-74.

71. Yao Y, Chen P, Diao J, Cheng G, Deng L, Anglin JL, et al. Selective inhibitors of histone methyltransferase DOT1L: design, synthesis, and crystallographic studies. J Am Chem Soc. 2011;133(42):16746-9.

72. Yu W, Smil D, Li F, Tempel W, Fedorov O, Nguyen KT, et al. Bromo-deazaSAH: a potent and selective DOT1L inhibitor. Bioorg Med Chem. 2013;21(7): 1787-94.
73. Daigle SR, Olhava EJ, Therkelsen CA, Basavapathruni A, Jin L, Boriack-Sjodin PA, et al. Potent inhibition of DOT1L as treatment of MLL-fusion leukemia. Blood. 2013;122(6):1017-25.

74. Liu W, Deng L, Song Y, Redell M. DOT1L inhibition sensitizes MLLrearranged AML to chemotherapy. PLoS One. 2014;9(5):e98270.

75. Deng L, Zhang L, Yao Y, Wang C, Redell MS, Dong S, et al. Synthesis, Activity and Metabolic Stability of Non-Ribose Containing Inhibitors of Histone Methyltransferase DOT1L. Med Chem Commun. 2013;4(5):822-6.

76. Yu W, Chory EJ, Wernimont AK, Tempel W, Scopton A, Federation A, et al. Catalytic site remodelling of the DOT1L methyltransferase by selective inhibitors. Nat Commun. 2012;3:1288.

77. Stein E, Garcia-Manero G, Rizzieri DA, Savona M, Tibes R, Altman JK, JongenLavrencic M, Döhner H, Armstrong S, Pollock RM, Waters N, Legler M, Thomson B, Daigle S, McDonald A, Campbell C, Olhava E, Hedrick EE, Lowenberg B, Copeland RA, Tallman MS: The DOT1L Inhibitor EPZ-5676: Safety and Activity in Relapsed/Refractory Patients with MLL-Rearranged Leukemia. In: 56th ASH Annual Meeting and Exposition: 2014; San Francisco, CA.

78. Zhang L, Deng L, Chen F, Yao Y, Wu B, Wei L, et al. Inhibition of histone H3K79 methylation selectively inhibits proliferation, self-renewal and metastatic potential of breast cancer. Oncotarget. 2014;5(21):10665-77.

79. Kim W, Kim R, Park G, Park JW, Kim JE. Deficiency of H3K79 histone methyltransferase Dot1-like protein (DOT1L) inhibits cell proliferation. J Biol Chem. 2012;287(8):5588-99.

80. Onder TT, Kara N, Cherry A, Sinha AU, Zhu N, Bernt KM, et al. Chromatinmodifying enzymes as modulators of reprogramming. Nature. 2012; 483(7391):598-602.

81. Guenther MG, Jenner RG, Chevalier B, Nakamura T, Croce CM, Canaani E, et al. Global and Hox-specific roles for the MLL1 methyltransferase. Proc Natl Acad Sci U S A. 2005;102(24):8603-8.

82. Zeleznik-Le NJ, Harden AM, Rowley JD. 11q23 translocations split the "AThook" cruciform DNA-binding region and the transcriptional repression domain from the activation domain of the mixed-lineage leukemia (MLL) gene. Proc Natl Acad Sci U S A. 1994;91(22):10610-4.

83. Abramovich C, Humphries RK. Hox regulation of normal and leukemic hematopoietic stem cells. Curr Opin Hematol. 2005;12(3):210-6.

84. Thiel AT, Blessington P, Zou T, Feather D, Wu X, Yan J, et al. MLL-AF9induced leukemogenesis requires coexpression of the wild-type MII allele. Cancer Cell. 2010;17(2):148-59.

85. Stavropoulos P, Blobel G, Hoelz A. Crystal structure and mechanism of human lysine-specific demethylase-1. Nat Struct Mol Biol. 2006;13(7):626-32.

86. Kerenyi MA, Shao Z, Hsu YJ, Guo G, Luc S, O'Brien K, et al. Histone demethylase $L s d 1$ represses hematopoietic stem and progenitor cell signatures during blood cell maturation. eLife. 2013;2:e00633.

87. Nakamura T, Mori T, Tada S, Krajewski W, Rozovskaia T, Wassell R, et al. ALL-1 is a histone methyltransferase that assembles a supercomplex of proteins involved in transcriptional regulation. Mol Cell. 2002;10(5):1119-28.

88. Harris WJ, Huang X, Lynch JT, Spencer GJ, Hitchin JR, Li Y, et al. The histone demethylase KDM1A sustains the oncogenic potential of MLL-AF9 leukemia stem cells. Cancer Cell. 2012;21(4):473-87.

89. Dent SY, Chandra J. The lasting influence of LSD1 in the blood. eLife. 2013; 2:e00963.

90. Lynch JT, Harris WJ, Somervaille TC. LSD1 inhibition: a therapeutic strategy in cancer? Expert Opin Ther Targets. 2012;16(12):1239-49.

91. Sprussel A, Schulte JH, Weber S, Necke M, Handschke K, Thor T, et al. Lysinespecific demethylase 1 restricts hematopoietic progenitor proliferation and is essential for terminal differentiation. Leukemia. 2012;26(9):2039-51.

92. Metzger E, Wissmann M, Yin N, Muller JM, Schneider R, Peters AH, et al. LSD1 demethylates repressive histone marks to promote androgenreceptor-dependent transcription. Nature. 2005;437(7057):436-9.

93. Wang J, Hevi S, Kurash JK, Lei H, Gay F, Bajko J, et al. The lysine demethylase LSD1 (KDM1) is required for maintenance of global DNA methylation. Nat Genet. 2009;41(1):125-9.

94. Huang J, Sengupta R, Espejo AB, Lee MG, Dorsey JA, Richter M, et al. p53 is regulated by the lysine demethylase LSD1. Nature. 2007; 449(7158):105-8.

95. Cho HS, Suzuki T, Dohmae N, Hayami S, Unoki M, Yoshimatsu M, et al. Demethylation of RB regulator MYPT1 by histone demethylase LSD1 promotes cell cycle progression in cancer cells. Cancer Res. 2011;71(3):655-60.

96. Yang J, Huang J, Dasgupta M, Sears N, Miyagi M, Wang B, et al. Reversible methylation of promoter-bound STAT3 by histone-modifying enzymes. Proc Natl Acad Sci U S A. 2010;107(50):21499-504. 
97. Liu X, Jia X, Yuan H, Ma K, Chen Y, Jin Y, et al. DNA methyltransferase 1 functions through C/ebpa to maintain hematopoietic stem and progenitor cells in zebrafish. J Hematol Oncol. 2015;8:15.

98. Goardon N, Marchi E, Atzberger A, Quek L, Schuh A, Soneji S, et al. Coexistence of LMPP-like and GMP-like leukemia stem cells in acute myeloid leukemia. Cancer Cell. 2011;19(1):138-52.

99. Berglund L, Bjorling E, Oksvold P, Fagerberg L, Asplund A, Szigyarto CA, et al. A genecentric Human Protein Atlas for expression profiles based on antibodies. Mol Cell Proteomics. 2008;7(10):2019-27.

100. Kahl P, Gullotti L, Heukamp LC, Wolf S, Friedrichs N, Vorreuther R, et al. Androgen receptor coactivators lysine-specific histone demethylase 1 and four and a half LIM domain protein 2 predict risk of prostate cancer recurrence. Cancer Res. 2006;66(23):11341-7.

101. Lim S, Janzer A, Becker A, Zimmer A, Schule R, Buettner R, et al. Lysinespecific demethylase 1 (LSD1) is highly expressed in ER-negative breast cancers and a biomarker predicting aggressive biology. Carcinogenesis. 2010;31(3):512-20.

102. Schulte JH, Lim S, Schramm A, Friedrichs N, Koster J, Versteeg R, et al. Lysine-specific demethylase 1 is strongly expressed in poorly differentiated neuroblastoma: implications for therapy. Cancer Res. 2009;69(5):2065-71.

103. Mohammad HP, Smitheman KN, Kamat CD, Soong D, Federowicz KE, Van Aller GS, et al. A DNA hypomethylation signature predicts antitumor activity of LSD1 inhibitors in SCLC. Cancer Cell. 2015;28(1):57-69.

104. Neelamegam R, Ricq EL, Malvaez M, Patnaik D, Norton S, Carlin SM, et al. Brain-penetrant LSD1 inhibitors can block memory consolidation. ACS Chem Neurosci. 2012;3(2):120-8.

105. Sorna V, Theisen ER, Stephens B, Warner SL, Bearss DJ, Vankayalapati H, et al. High-throughput virtual screening identifies novel N'-(1-phenylethylidene)benzohydrazides as potent, specific, and reversible LSD1 inhibitors. J Med Chem. 2013:56(23):9496-508

106. Zheng YC, Duan YC, Ma JL, Xu RM, Zi X, Lv WL, et al. Triazoledithiocarbamate based selective lysine specific demethylase 1 (LSD1) inactivators inhibit gastric cancer cell growth, invasion, and migration. J Med Chem. 2013;56(21):8543-60.

107. Fiskus W, Sharma S, Shah B, Portier BP, Devaraj SG, Liu K, et al. Highly effective combination of LSD1 (KDM1A) antagonist and pan-histone deacetylase inhibitor against human AML cells. Leukemia. 2014;28(11):2155-64.

108. Prusevich P, Kalin JH, Ming SA, Basso M, Givens J, Li X, et al. A Selective Phenelzine Analogue Inhibitor of Histone Demethylase LSD1. ACS Chem Biol. 2014;9(6):1284-93.

109. Huang Y, Greene E, Murray Stewart T, Goodwin AC, Baylin SB, Woster PM, et al. Inhibition of lysine-specific demethylase 1 by polyamine analogues results in reexpression of aberrantly silenced genes. Proc Natl Acad Sci U S A. 2007; 104(19):8023-8.

110. Sharma SK, Wu Y, Steinbergs N, Crowley ML, Hanson AS, Casero RA, et al. (Bis)urea and (bis)thiourea inhibitors of lysine-specific demethylase 1 as epigenetic modulators. J Med Chem. 2010;53(14):5197-212

111. Feng Z, Yao Y, Zhou C, Chen F, Wu F, Wei L, et al. Pharmacological inhibition of LSD1 for the treatment of MLL-rearranged leukemia. J Hematol Oncol. 2016;9(1):24.

112. Wu F, Zhou C, Yao Y, Wei L, Feng Z, Deng L, et al. 3-(Piperidin-4ylmethoxy)pyridine Containing Compounds Are Potent Inhibitors of Lysine Specific Demethylase 1. J Med Chem. 2016;59(1):253-63.

113. Suzuki T, Miyata N. Lysine demethylases inhibitors. J Med Chem. 2011; 54(24):8236-50.

114. Dou Y, Milne TA, Tackett AJ, Smith ER, Fukuda A, Wysocka J, et al. Physical association and coordinate function of the $\mathrm{H} 3 \mathrm{~K} 4$ methyltransferase MLL1 and the H4 K16 acetyltransferase MOF. Cell. 2005;121(6):873-85.

115. Cao F, Chen Y, Cierpicki T, Liu Y, Basrur V, Lei M, et al. An Ash2L/RbBP5 heterodimer stimulates the MLL1 methyltransferase activity through coordinated substrate interactions with the MLL1 SET domain. PLOS One. 2010;5(11):e14102.

116. Cao F, Townsend EC, Karatas H, Xu J, Li L, Lee S, et al. Targeting MLL1 H3K4 methyltransferase activity in mixed-lineage leukemia. Mol Cell. 2014;53(2): 247-61

117. Karatas H, Townsend EC, Cao F, Chen Y, Bernard D, Liu L, et al. High-affinity, small-molecule peptidomimetic inhibitors of MLL1/WDR5 protein-protein interaction. J Am Chem Soc. 2013;135(2):669-82.

118. Cao R, Wang L, Wang H, Xia L, Erdjument-Bromage $H$, Tempst $P$, et al. Role of histone $\mathrm{H} 3$ lysine 27 methylation in Polycomb-group silencing. Science. 2002:298(5595):1039-43.
119. Muller J, Hart CM, Francis NJ, Vargas ML, Sengupta A, Wild B, et al. Histone methyltransferase activity of a Drosophila Polycomb group repressor complex. Cell. 2002;111(2):197-208.

120. Kuzmichev A, Nishioka K, Erdjument-Bromage H, Tempst P, Reinberg D. Histone methyltransferase activity associated with a human multiprotein complex containing the Enhancer of Zeste protein. Genes Dev. 2002;16(22):2893-905.

121. Pirrotta V. Polycombing the genome: $P c G$, trxG, and chromatin silencing. Cell. 1998:93(3):333-6.

122. Francis NJ, Kingston RE. Mechanisms of transcriptional memory. Nat Rev Mol Cell Biol. 2001;2(6):409-21.

123. Simon JA, Tamkun JW. Programming off and on states in chromatin: mechanisms of Polycomb and trithorax group complexes. Curr Opin Genet Dev. 2002;12(2):210-8

124. Cao R, Zhang Y. SUZ12 is required for both the histone methyltransferase activity and the silencing function of the EED-EZH2 complex. Mol Cell. 2004; 15(1):57-67.

125. Pasini D, Bracken AP, Jensen MR, Lazzerini Denchi E, Helin K. Suz12 is essential for mouse development and for EZH2 histone methyltransferase activity. EMBO J. 2004;23(20):4061-71.

126. Crea F, Paolicchi E, Marquez VE, Danesi R. Polycomb genes and cancer: time for clinical application? Crit Rev Oncol Hematol. 2012;83(2):184-93.

127. Squazzo SL, O'Geen H, Komashko VM, Krig SR, Jin VX, Jang SW, et al. Suz12 binds to silenced regions of the genome in a cell-type-specific manner. Genome Res. 2006;16(7):890-900.

128. Vire E, Brenner C, Deplus R, Blanchon L, Fraga M, Didelot C, et al. The Polycomb group protein EZH2 directly controls DNA methylation. Nature. 2006;439(7078):871-4

129. O'Carroll D, Erhardt S, Pagani M, Barton SC, Surani MA, Jenuwein T. The polycomb-group gene Ezh2 is required for early mouse development. Mol Cell Biol. 2001:21(13):4330-6.

130. Wang X, Zhao H, Lv L, Bao L, Han S. Prognostic Significance of EZH2 Expression in Non-Small Cell Lung Cancer: A Meta-analysis. Scientific reports. 2016;6:19239.

131. Kleer CG, Cao Q, Varambally S, Shen R, Ota I, Tomlins SA, et al. EZH2 is a marker of aggressive breast cancer and promotes neoplastic transformation of breast epithelial cells. Proc Natl Acad Sci U S A. 2003;100(20):11606-11.

132. Simon JA, Lange CA. Roles of the EZH2 histone methyltransferase in cancer epigenetics. Mutat Res. 2008:647(1-2):21-9.

133. Li Z, Wang Y, Qiu J, Li Q, Yuan C, Zhang W, et al. The polycomb group protein $\mathrm{EZH} 2$ is a novel therapeutic target in tongue cancer. Oncotarget. 2013;4(12):2532-49.

134. Varambally S, Dhanasekaran SM, Zhou M, Barrette TR, Kumar-Sinha C, Sanda MG, et al. The polycomb group protein EZH2 is involved in progression of prostate cancer. Nature. 2002;419(6907):624-9.

135. Weikert S, Christoph F, Kollermann J, Muller M, Schrader M, Miller K, et al. Expression levels of the $\mathrm{EZH} 2$ polycomb transcriptional repressor correlate with aggressiveness and invasive potential of bladder carcinomas. Int J Mol Med. 2005;16(2):349-53.

136. Shi J, Wang E, Zuber J, Rappaport A, Taylor M, Johns C, et al. The Polycomb complex PRC2 supports aberrant self-renewal in a mouse model of MLLAF9:Nras(G12D) acute myeloid leukemia. Oncogene. 2013:32(7):930-8.

137. Suva ML, Riggi N, Janiszewska M, Radovanovic I, Provero P, Stehle JC, et al. $\mathrm{EZH} 2$ is essential for glioblastoma cancer stem cell maintenance. Cancer Res. 2009;69(24):9211-8.

138. Knutson SK, Kawano S, Minoshima Y, Warholic NM, Huang KC, Xiao Y, et al. Selective inhibition of EZH2 by EPZ-6438 leads to potent antitumor activity in EZH2-mutant non-Hodgkin lymphoma. Mol Cancer Ther. 2014;13(4):842-54.

139. McCabe MT, Ott HM, Ganji G, Korenchuk S, Thompson C, Van Aller GS, et al. EZH2 inhibition as a therapeutic strategy for lymphoma with EZH2activating mutations. Nature. 2012;492(7427):108-12.

140. Lohr JG, Stojanov P, Lawrence MS, Auclair D, Chapuy B, Sougnez C, et al. Discovery and prioritization of somatic mutations in diffuse large B-cell lymphoma (DLBCL) by whole-exome sequencing. Proc Natl Acad Sci U S A. 2012;109(10):3879-84.

141. Morin RD, Johnson NA, Severson TM, Mungall AJ, An J, Goya R, et al. Somatic mutations altering EZH2 (Tyr641) in follicular and diffuse large Bcell lymphomas of germinal-center origin. Nat Genet. 2010;42(2):181-5.

142. Morin RD, Mendez-Lago M, Mungall AJ, Goya R, Mungall KL, Corbett RD, et al. Frequent mutation of histone-modifying genes in non-Hodgkin lymphoma. Nature. 2011;476(7360):298-303.

143. Sneeringer CJ, Scott MP, Kuntz KW, Knutson SK, Pollock RM, Richon VM, et al. Coordinated activities of wild-type plus mutant EZH2 drive tumor-associated 
hypertrimethylation of lysine 27 on histone H3 (H3K27) in human B-cell lymphomas. Proc Natl Acad Sci U S A. 2010;107(49):20980-5.

144. McCabe MT, Graves AP, Ganji G, Diaz E, Halsey WS, Jiang Y, et al. Mutation of A677 in histone methyltransferase EZH2 in human B-cell lymphoma promotes hypertrimethylation of histone $\mathrm{H} 3$ on lysine 27 (H3K27). Proc Natl Acad Sci U S A. 2012;109(8):2989-94.

145. Wigle TJ, Knutson SK, Jin L, Kuntz KW, Pollock RM, Richon VM, et al. The Y641C mutation of EZH2 alters substrate specificity for histone H3 lysine 27 methylation states. FEBS Lett. 2011;585(19):3011-4.

146. Bradley WD, Arora S, Busby J, Balasubramanian S, Gehling VS, Nasveschuk CG, et al. EZH2 inhibitor efficacy in non-Hodgkin's lymphoma does not require suppression of H3K27 monomethylation. Chemistry \& biology. 2014;21(11):1463-75.

147. Garapaty-Rao S, Nasveschuk C, Gagnon A, Chan EY, Sandy P, Busby J, et al. Identification of EZH2 and $\mathrm{EZH} 1$ small molecule inhibitors with selective impact on diffuse large B cell lymphoma cell growth. Chemistry \& biology. 2013;20(11):1329-39.

148. Knutson SK, Wigle TJ, Warholic NM, Sneeringer CJ, Allain CJ, Klaus CR, et al. A selective inhibitor of EZH2 blocks H3K27 methylation and kills mutant lymphoma cells. Nat Chem Biol. 2012;8(11):890-6.

149. Konze KD, Ma A, Li F, Barsyte-Lovejoy D, Parton T, Macnevin CJ, et al. An orally bioavailable chemical probe of the Lysine Methyltransferases EZH2 and EZH1. ACS Chem Biol. 2013;8(6):1324-34.

150. Xu X, Zhao J, Xu Z, Peng B, Huang Q, Arnold E, et al. Structures of human cytosolic NADP-dependent isocitrate dehydrogenase reveal a novel selfregulatory mechanism of activity. J Biol Chem. 2004;279(32):33946-57.

151. Haselbeck RJ, McAlister-Henn L. Function and expression of yeast mitochondrial NAD- and NADP-specific isocitrate dehydrogenases. J Biol Chem. 1993;268(16):12116-22.

152. Parsons DW, Jones S, Zhang X, Lin JC, Leary RJ, Angenendt P, et al. An integrated genomic analysis of human glioblastoma multiforme. Science. 2008;321(5897):1807-12.

153. Hartmann C, Meyer J, Balss J, Capper D, Mueller W, Christians A, et al. Type and frequency of $\mathrm{IDH} 1$ and $\mathrm{IDH} 2$ mutations are related to astrocytic and oligodendroglial differentiation and age: a study of 1,010 diffuse gliomas. Acta Neuropathol. 2009;118(4):469-74.

154. Yan H, Parsons DW, Jin G, McLendon R, Rasheed BA, Yuan W, et al. IDH1 and IDH2 mutations in gliomas. N Engl J Med. 2009;360(8):765-73.

155. Bleeker FE, Lamba S, Leenstra S, Troost D, Hulsebos T, Vandertop WP, et al IDH1 mutations at residue p.R132 (IDH1(R132)) occur frequently in highgrade gliomas but not in other solid tumors. Hum Mutat. 2009;30(1):7-11.

156. Balss J, Meyer J, Mueller W, Korshunov A, Hartmann C, von Deimling A. Analysis of the IDH1 codon 132 mutation in brain tumors. Acta Neuropathol. 2008;116(6):597-602.

157. Gross S, Cairns RA, Minden MD, Driggers EM, Bittinger MA, Jang HG, et al. Cancer-associated metabolite 2-hydroxyglutarate accumulates in acute myelogenous leukemia with isocitrate dehydrogenase 1 and 2 mutations. J Exp Med. 2010;207(2):339-44.

158. Amary MF, Bacsi K, Maggiani F, Damato S, Halai D, Berisha F, et al. IDH1 and $\mathrm{IDH} 2$ mutations are frequent events in central chondrosarcoma and central and periosteal chondromas but not in other mesenchymal tumours. J Pathol. 2011;224(3):334-43.

159. Figueroa ME, Abdel-Wahab O, Lu C, Ward PS, Patel J, Shih A, et al. Leukemic IDH1 and IDH2 mutations result in a hypermethylation phenotype, disrupt TET2 function, and impair hematopoietic differentiation. Cancer Cell. 2010;18(6):553-67.

160. Marcucci G, Maharry K, Wu YZ, Radmacher MD, Mrozek K, Margeson D, et al. $\mathrm{IDH} 1$ and IDH2 gene mutations identify novel molecular subsets within de novo cytogenetically normal acute myeloid leukemia: a Cancer and Leukemia Group B study. J Clin Oncol Off J Am Soc Clin Oncol. 2010;28(14):2348-55.

161. Dang L, Jin S, Su SM. IDH mutations in glioma and acute myeloid leukemia. Trends Mol Med. 2010;16(9):387-97.

162. Yen KE, Bittinger MA, Su SM, Fantin VR. Cancer-associated IDH mutations: biomarker and therapeutic opportunities. Oncogene. 2010;29(49):6409-17.

163. Watanabe T, Nobusawa S, Kleihues $P$, Ohgaki H. IDH1 mutations are early events in the development of astrocytomas and oligodendrogliomas. Am J Pathol. 2009;174(4):1149-53.

164. Dang L, White DW, Gross S, Bennett BD, Bittinger MA, Driggers EM, et al. Cancer-associated IDH1 mutations produce 2-hydroxyglutarate. Nature. 2009;462(7274):739-44.

165. Zhao S, Lin Y, Xu W, Jiang W, Zha Z, Wang P, et al. Glioma-derived mutations in IDH1 dominantly inhibit IDH1 catalytic activity and induce HIF1alpha. Science. 2009;324(5924):261-5.
166. Ward PS, Patel J, Wise DR, Abdel-Wahab O, Bennett BD, Coller HA, et al. The common feature of leukemia-associated IDH1 and IDH2 mutations is a neomorphic enzyme activity converting alpha-ketoglutarate to 2hydroxyglutarate. Cancer Cell. 2010;17(3):225-34.

167. Xu W, Yang H, Liu Y, Yang Y, Wang P, Kim SH, et al. Oncometabolite 2hydroxyglutarate is a competitive inhibitor of alpha-ketoglutaratedependent dioxygenases. Cancer Cell. 2011;19(1):17-30.

168. Turcan S, Rohle D, Goenka A, Walsh LA, Fang F, Yilmaz E, et al. IDH1 mutation is sufficient to establish the glioma hypermethylator phenotype. Nature. 2012;483(7390):479-83.

169. Noushmehr H, Weisenberger DJ, Diefes K, Phillips HS, Pujara K, Berman BP et al. Identification of a CpG island methylator phenotype that defines a distinct subgroup of glioma. Cancer Cell. 2010;17(5):510-22.

170. Lu C, Ward PS, Kapoor GS, Rohle D, Turcan S, Abdel-Wahab O, et al. IDH mutation impairs histone demethylation and results in a block to cell differentiation. Nature. 2012;483(7390):474-8.

171. Popovici-Muller J, Saunders JO, Salituro FG, Travins JM, Yan S, Zhao F, et al. Discovery of the First Potent Inhibitors of Mutant IDH1 That Lower Tumor 2-HG in Vivo. ACS Med Chem Lett. 2012;3(10):850-5.

172. Rohle D, Popovici-Muller J, Palaskas N, Turcan S, Grommes C, Campos C, et al. An inhibitor of mutant IDH1 delays growth and promotes differentiation of glioma cells. Science. 2013;340(6132):626-30.

173. Wang F, Travins J, DeLaBarre B, Penard-Lacronique V, Schalm S, Hansen E, et al. Targeted inhibition of mutant IDH2 in leukemia cells induces cellular differentiation. Science. 2013;340(6132):622-6

174. Zheng B, Yao Y, Liu Z, Deng L, Anglin JL, Jiang H, et al. Crystallographic Investigation and Selective Inhibition of Mutant Isocitrate Dehydrogenase. ACS Med Chem Lett. 2013:4(6):542-6.

175. Liu Z, Yao Y, Kogiso M, Zheng B, Deng L, Qiu JJ, et al. Inhibition of cancerassociated mutant isocitrate dehydrogenases: synthesis, structure-activity relationship, and selective antitumor activity. J Med Chem. 2014;57(20): 8307-18.

176. Wu F, Jiang H, Zheng B, Kogiso M, Yao Y, Zhou C, et al. Inhibition of Cancer-Associated Mutant Isocitrate Dehydrogenases by 2-Thiohydantoin Compounds. J Med Chem. 2015;58(17):6899-908.

177. Deng G, Shen J, Yin M, McManus J, Mathieu M, Gee P, et al. Selective inhibition of mutant isocitrate dehydrogenase $1(\mathrm{IDH} 1)$ via disruption of a metal binding network by an allosteric small molecule. J Biol Chem. 2015; 290(2):762-74.

178. Baldwin RM, Morettin A, Cote J. Role of PRMTs in cancer: Could minor isoforms be leaving a mark? World J Biol Chem. 2014;5(2):115-29.

179. Tachibana M, Sugimoto K, Nozaki M, Ueda J, Ohta T, Ohki M, et al. G9a histone methyltransferase plays a dominant role in euchromatic histone $\mathrm{H} 3$ lysine 9 methylation and is essential for early embryogenesis. Genes Dev. 2002;16(14):1779-91.

180. Huang J, Dorsey J, Chuikov S, Perez-Burgos L, Zhang X, Jenuwein T, et al. G9a and Glp methylate lysine 373 in the tumor suppressor p53. J Biol Chem. 2010;285(13):9636-41.

181. Kondo Y, Shen L, Ahmed S, Boumber Y, Sekido Y, Haddad BR, et al. Downregulation of histone $\mathrm{H} 3$ lysine 9 methyltransferase G9a induces centrosome disruption and chromosome instability in cancer cells. PLoS One. 2008;3(4):e2037.

182. Kondo Y, Shen L, Suzuki S, Kurokawa T, Masuko K, Tanaka Y, et al. Alterations of DNA methylation and histone modifications contribute to gene silencing in hepatocellular carcinomas. Hepatol Res. 2007;37(11):974-83.

183. Kubicek S, O'Sullivan RJ, August EM, Hickey ER, Zhang Q, Teodoro ML, et al. Reversal of H3K9me2 by a small-molecule inhibitor for the G9a histone methyltransferase. Mol Cell. 2007;25(3):473-81.

184. Vedadi M, Barsyte-Lovejoy D, Liu F, Rival-Gervier S, Allali-Hassani A, Labrie V, et al. A chemical probe selectively inhibits G9a and GLP methyltransferase activity in cells. Nat Chem Biol. 2011;7(8):566-74.

185. Sweis RF, Pliushchev M, Brown PJ, Guo J, Li F, Maag D, et al. Discovery and development of potent and selective inhibitors of histone methyltransferase g9a. ACS Med Chem Lett. 2014;5(2):205-9.

186. Kalari KR, Hebbring SJ, Chai HS, Li L, Kocher JP, Wang L, et al. Copy number variation and cytidine analogue cytotoxicity: a genome-wide association approach. BMC Genomics. 2010;11:357.

187. Komatsu S, Imoto I, Tsuda H, Kozaki Kl, Muramatsu T, Shimada Y, et al. Overexpression of SMYD2 relates to tumor cell proliferation and malignant outcome of esophageal squamous cell carcinoma. Carcinogenesis. 2009; 30(7):1139-46 
188. Ferguson AD, Larsen NA, Howard T, Pollard H, Green I, Grande C, et al. Structural basis of substrate methylation and inhibition of SMYD2. Structure. 2011;19(9):1262-73.

189. Nguyen H, Allali-Hassani A, Antonysamy S, Chang S, Chen LH, Curtis C, et al. LLY-507, a cell-active, potent, and selective inhibitor of protein-lysine methyltransferase SMYD2. J Biol Chem. 2015;290(22):13641-53.

190. Sack JS, Thieffine S, Bandiera T, Fasolini M, Duke GJ, Jayaraman L, et al. Structural basis for CARM1 inhibition by indole and pyrazole inhibitors. The Biochemical journal. 2011;436(2):331-9.

191. Kaniskan HU, Szewczyk MM, Yu Z, Eram MS, Yang X, Schmidt K, et al. A potent, selective and cell-active allosteric inhibitor of protein arginine methyltransferase 3 (PRMT3). Angew Chem Int Ed Engl. 2015;54(17):5166-70.

192. Mitchell LH, Drew AE, Ribich SA, Rioux N, Swinger KK, Jacques SL, et al. Aryl pyrazoles as potent inhibitors of arginine methyltransferases: identification of the first PRMT6 tool compound. ACS Med Chem Lett. 2015;6(6):655-9.

193. Eram MS, Shen Y, Szewczyk MM, Wu H, Senisterra G, Li F, et al. A potent, selective, and cell-active inhibitor of human type I protein arginine methyltransferases. ACS Chem Biol. 2016;11(3):772-81.

194. Chan-Penebre E, Kuplast KG, Majer CR, Boriack-Sjodin PA, Wigle TJ, Johnston $L D$, et al. A selective inhibitor of PRMT5 with in vivo and in vitro potency in MCL models. Nat Chem Biol. 2015;11(6):432-7.

195. Kruidenier L, Chung CW, Cheng Z, Liddle J, Che K, Joberty G, et al. A selective jumonji H3K27 demethylase inhibitor modulates the proinflammatory macrophage response. Nature. 2012;488(7411):404-8.

196. Cui Y, Tong H, Du X, Li B, Gale RP, Qin T, et al. Impact of TET2, SRSF2, ASXL1 and SETBP1 mutations on survival of patients with chronic myelomonocytic leukemia. Exp Hematol Oncol. 2015;4:14.

197. Guillaumet-Adkins A, Richter J, Odero MD, Sandoval J, Agirre X, Catala A, et al. Hypermethylation of the alternative AWT1 promoter in hematological malignancies is a highly specific marker for acute myeloid leukemias despite high expression levels. J Hematol Oncol. 2014;7:4.

198. Hajkova H, Fritz MH, Haskovec C, Schwarz J, Salek C, Markova J, et al. CBFBMYH11 hypomethylation signature and PBX3 differential methylation revealed by targeted bisulfite sequencing in patients with acute myeloid leukemia. J Hematol Oncol. 2014:7:66.

199. Shenoy N, Vallumsetla N, Zou Y, Galeas JN, Shrivastava M, Hu C, et al. Role of DNA methylation in renal cell carcinoma. J Hematol Oncol. 2015;8:88

200. Cang S, Ma Y, Chiao JW, Liu D. Phenethyl isothiocyanate and paclitaxel synergistically enhanced apoptosis and alpha-tubulin hyperacetylation in breast cancer cells. Exp Hematol Oncol. 2014;3(1):5.

\section{Submit your next manuscript to BioMed Central and we will help you at every step:}

- We accept pre-submission inquiries

- Our selector tool helps you to find the most relevant journal

- We provide round the clock customer support

- Convenient online submission

- Thorough peer review

- Inclusion in PubMed and all major indexing services

- Maximum visibility for your research

Submit your manuscript at wuw biomedcentral.com/submit

) Biomed Central 